University of Nebraska - Lincoln

DigitalCommons@University of Nebraska - Lincoln

2006

\title{
Primaquine: Report from CDC Expert Meeting on Malaria Chemoprophylaxis I
}

David R. Hill

London School of Hygiene \& Tropical Medicine, david.hill@uclh.org

J. Kevin Baird

ALERTAsia Foundation, jkevinbaird@yahoo.com

Monica E. Parise

Centers for Disease Control and Prevention, mparise@cdc.gov

Linda S. Lewis

Butte County Department of Public Health, llewis@buttecounty.net

Edward T. Ryan

Massachusetts General Hospital, etryan@partners.org

See next page for additional authors

Follow this and additional works at: https://digitalcommons.unl.edu/usnavyresearch

Hill, David R.; Baird, J. Kevin; Parise, Monica E.; Lewis, Linda S.; Ryan, Edward T.; and Magill, Alan J., "Primaquine: Report from CDC Expert Meeting on Malaria Chemoprophylaxis I" (2006). U.S. Navy Research. 60.

https://digitalcommons.unl.edu/usnavyresearch/60

This Article is brought to you for free and open access by the U.S. Department of Defense at DigitalCommons@University of Nebraska - Lincoln. It has been accepted for inclusion in U.S. Navy Research by an authorized administrator of DigitalCommons@University of Nebraska - Lincoln. 


\section{Authors}

David R. Hill, J. Kevin Baird, Monica E. Parise, Linda S. Lewis, Edward T. Ryan, and Alan J. Magill 


\title{
PRIMAQUINE: REPORT FROM CDC EXPERT MEETING ON MALARIA CHEMOPROPHYLAXIS I
}

\begin{abstract}
DAVID R. HILL, * J. KEVIN BAIRD, MONICA E. PARISE, LINDA S. LEWIS, EDWARD T. RYAN, AND ALAN J. MAGILL
National Travel Health Network and Centre, London, England; London School of Hygiene and Tropical Medicine, London, England; ALERTAsia Foundation, Jakarta, Indonesia; Division of Parasitic Diseases, National Center for Infectious Diseases, Centers for Disease Control and Prevention, Atlanta, Georgia; Butte County Department of Public Health, Oroville, CA; Division of Infectious Diseases, Massachusetts General Hospital and Harvard Medical School, Boston, Massachusetts; Walter Reed Army Institute of Research, Silver Springs, Maryland
\end{abstract}

\begin{abstract}
Primaquine phosphate has been used for preventing relapse of Plasmodium vivax and P. ovale malaria since the early 1950s, based on its ability to kill latent (hypnozoite) and developing liver stages of these parasites. There are three uses for primaquine in malaria: radical cure of established infection with $P$. vivax or $P$. ovale malaria; presumptive anti-relapse therapy (PART; terminal prophylaxis) in persons with extensive exposure to these parasites; and primary prophylaxis against all malaria species. All persons for whom primaquine is being considered must have a glucose-6-phosphate dehydrogenase (G6PD) enzyme level checked before use, and persons who have a deficiency of G6PD must not take primaquine for prophylaxis or PART. The recommended adult dose for PART based on clinical trials and expert opinion is $30 \mathrm{mg}$ base daily for 14 days, started on return from a malarious region and overlapping with a blood schizonticide. The adult dose for primary prophylaxis is $30 \mathrm{mg}$ daily begun 1 day before travel and continued for 7 days after return. This review will examine the evidence for these recommendations.
\end{abstract}

\section{SUMMARY}

Indications. Presumptive anti-relapse therapy (terminal prophylaxis) in persons heavily exposed to Plasmodium vivax or P. ovale.

Prophylaxis (causal), as a second line agent, for prevention of all Plasmodium species (not currently Food and Drug Administration [FDA]-approved for this indication).

Radical cure in persons with a confirmed bloodstream infection with $P$. vivax or $P$. ovale.

Dosing. Note: $15 \mathrm{mg}$ base $=26.3 \mathrm{mg}$ of the phosphate salt; doses for all anti-malarials in this document are expressed in the base form. Glucose-6-phosphate dehydrogenase (G6PD) testing must be performed before a patient takes primaquine.

Adult. Presumptive anti-relapse therapy: $30 \mathrm{mg}$ daily for 14 days, based on clinical trials data (A-II $\dagger$ ) and current expert opinion (C-III). $\neq$ Dosing should overlap with a blood schizonticide.

Prophylaxis: $30 \mathrm{mg}$ daily started 1 day before travel, taken daily during travel and for 7 days after travel (A-I).

Radical cure: $30 \mathrm{mg}$ daily for 14 days to overlap with the blood schizonticide agent (A-I).

Pediatric. Presumptive anti-relapse therapy: $0.5 \mathrm{mg} / \mathrm{kg}$ (up to a maximum of $30 \mathrm{mg}$ ) daily for 14 days (B-III).

Prophylaxis: $0.5 \mathrm{mg} / \mathrm{kg}$ daily (up to a maximum $30 \mathrm{mg}$ ) started 1 day before travel, taken daily during travel and for 7 days after travel (B-I for use in children 7 years of age and older; B-III for use in children 6 years of age and younger).

Radical cure: $0.5 \mathrm{mg} / \mathrm{kg}$ daily (up to a maximum $30 \mathrm{mg}$ ) for 14 days to overlap with the blood schizonticide agent (A-I).

Efficacy. Presumptive anti-relapse therapy: high ( $\sim 95 \%$ and greater) at doses of $30 \mathrm{mg}$ daily for 14 days (in combination with a blood schizonticide such as chloroquine). Although $15 \mathrm{mg}$ daily $(0.25 \mathrm{mg} / \mathrm{kg} / \mathrm{d})$ for 14 days effectively prevents relapse with $P$. vivax from many areas of the world,

* Address correspondence to David R. Hill, MD, DTM\&H, National Travel Health Network and Centre and London School of Hygiene \& Tropical Medicine Mortimer Market Centre, Capper Street, London WC1E 6AU, UK. E-mail: david.hill@uclh.org some strains of $P$. vivax (principally found in Southeast Asia and South Pacific) may not be eradicated at this dosage.

Prophylaxis: clinical trials indicate $>85 \%$ protective efficacy against $P$. falciparum and primary $P$. vivax infections at a dose of $30 \mathrm{mg}$ daily.

Radical cure: high (> 90\%) with medication compliance and $30 \mathrm{mg}$ daily equivalent dosing.

Adverse drug reactions. Most common mild/moderate adverse drug reactions (ADRs) $\Delta$ : abdominal pain, nausea, vomiting.

Severe $\delta$ : hemolysis in persons with G6PD deficiency. Methemoglobinemia occurs, but is not reported to be clinically significant at dosages used for prophylaxis. In studies, $0-2 \%$ of persons have reported a severe reaction and $0-2 \%$ have discontinued prophylaxis because of ADRs.

\section{Contraindications.}

- G6PD deficiency

- NADH methemoglobin reductase deficiency

- Known hypersensitivity to primaquine or related drugs (e.g., iodoquinol)

- Persons receiving treatment with other potentially hemolytic drugs

- Pregnancy (even if a pregnant woman is G6PD normal, the fetus may not be)

- The packaging label states that primaquine is contraindicated in persons with illnesses manifest by a tendency to granulocytopenia (lupus erythematosus and rheumatoid arthritis), but data are lacking on this association at dosages used in malaria chemoprophylaxis.

Precautions. Must have G6PD testing performed before using primaquine.

Drug interactions. Primaquine $30 \mathrm{mg}$ /day has caused severe methemoglobinemia in HIV-infected individuals when used for prophylaxis of Pneumocystis jiroveci (previously P. carinii) pneumonia, especially in those currently or recently taking dapsone.

Use during pregnancy. Contraindicated.

Use during breastfeeding. Use only if infant is tested for G6PD deficiency and has normal enzyme levels.

Use in children. May be used in children of any age. 
$\dagger$ Infectious Diseases Society of America-United States Public Health Service Grading System for ranking recommendations in clinical guidelines. ${ }^{1}$ Strength of recommendation: A, good evidence to support a recommendation for use; B, moderate evidence to support a recommendation for use; $\mathrm{C}$, poor evidence to support a recommendation; D, moderate evidence to support a recommendation against use; E, good evidence to support a recommendation against use. Quality of evidence: I, evidence from one or more properly randomized, controlled trials; II, evidence from one or more well-designed clinical trials, without randomization; from cohort or casecontrolled analytic studies (preferably from $>1$ center); from multiple time-series; or from dramatic results from uncontrolled experiments; III, evidence from opinions of respected authorities, based on clinical experience, descriptive studies, or reports of expert committees.

$\$ 15 \mathrm{mg}$ daily for 14 days is the current FDA-approved regimen; $30 \mathrm{mg}$ daily for 14 days is not currently an FDA-approved regimen, although clinical trials data (A-II) and current expert opinion (C-III) support the use of the higher dose.

$\Delta \mathrm{Mild} /$ moderate ADRs enumerated if reported in at least two studies at $>2 \%$ frequency; ordered according to number of studies that reported this ADR.

$\delta$ Severe ADRs may be defined in various ways in different studies, but include ADRs interfering with activities of daily living or prompting the seeking of medical attention. Severe ADRs may also include any of the reactions listed under mild to moderate ADRs if they are severe in intensity.

\section{INTRODUCTION}

Since its approval in 1952 by the FDA, primaquine has been the only available agent capable of preventing relapse after infection with Plasmodium vivax and $P$. ovale malaria species. This has been termed radical cure. Primaquine, an 8-aminoquinoline, kills latent (hypnozoite) and developing liver stages of these plasmodia. At therapeutic doses, primaquine also exerts lethal activity against the asexual blood stages of $P$. vivax but not those of $P$. falciparum..$^{2-4}$ When primaquine is given presumptively in conjunction with a blood stage prophylaxis agent to an individual who has traveled to an area of the world where $P$. vivax or $P$. ovale occurs, therapy is called terminal prophylaxis or "presumptive antirelapse therapy" (PART). PART is a term that more accurately defines its role and is the term that will be used. Some health authorities recommend that PART be administered to individuals after substantial risk of infection with $P$. vivax or $P$. ovale,${ }^{5,6}$ although a consensus defining "substantial" risk is lacking.

Primaquine may also be used as a "primary" prophylactic because it prevents primary parasitemia by all species of malaria by destroying these parasites in the liver before they reach the bloodstream and cause disease. ${ }^{7}$ Prophylactic agents that prevent the blood stage infection by killing developing liver stage parasites are referred to as "causal" prophylactics. Primaquine may cause lethal hemolysis when administered to individuals deficient in G6PD. All persons who receive primaquine are required to have testing for G6PD. Primaquine should not be administered for prophylaxis in individuals deficient in G6PD.

Primaquine's mechanism of action is poorly understood, but it severely disrupts the metabolic processes of plasmodial mitochondria. The anti-malarial activity is probably attributable to interference with the function of ubiquinone as an electron carrier in the respiratory chain. Another potential mechanism of action against plasmodia is the production of highly reactive metabolites that generate toxic intracellular oxidative potentials.

\section{RECOMMENDED USES AND DOSING OF PRIMAQUINE}

There are three uses for primaquine in malaria: prophylaxis, presumptive anti-relapse therapy (terminal prophylaxis) for $P$. vivax and $P$. ovale, and radical cure after $P$. vivax or $P$. ovale clinical disease. The focus of this review is the use of primaquine for prophylaxis and PART. Note: $15 \mathrm{mg}$ base = $26.3 \mathrm{mg}$ of the phosphate salt; doses for all anti-malarials in this document are expressed in the base form. G6PD testing must be performed before prescribing primaquine.

Prophylaxis. Prophylaxis prevents primary parasitemia (as opposed to PART that is used to prevent relapse of $P$. vivax and $P$. ovale by killing hypnozoites). When primaquine is used as prophylaxis, a dose of $30 \mathrm{mg}$ daily (adult dose) beginning 1 day before exposure and continuing for 1 week after departure from an area with malaria is recommended..$^{5-7}$ For adults $<60 \mathrm{~kg}$ and children, the Centers for Disease Control and Prevention (CDC)-recommended dosage is $0.5 \mathrm{mg} / \mathrm{kg} / \mathrm{d}$ (to a maximum daily dose of $30 \mathrm{mg}$ ). ${ }^{5}$

PART (terminal prophylaxis). PART constitutes presumptive therapy to prevent relapse by $P$. vivax and $P$. ovale by killing liver stage hypnozoites. For both historical and safety considerations in the era before G6PD testing was available, the current FDA-approved dose is $15 \mathrm{mg}$ daily for 14 days. However, P. vivax strains acquired in Papua (Indonesian New Guinea), areas of Oceania, and some other parts of the world require a higher dose of primaquine to prevent relapse. To achieve reliable eradication of parasites and with G6PD testing available, the $\mathrm{CDC}$ has recommended an increase in dose from 15 to $30 \mathrm{mg}$ daily for 14 days for adults. ${ }^{5}$ Expert opinion and clinical trials data support this recommendation although clinicians should be aware that the $30-\mathrm{mg}$ daily dose is not FDA approved. The pediatric dose has also been increased from 0.25 to $0.5 \mathrm{mg} / \mathrm{kg}$ once daily (to a maximum of $30 \mathrm{mg}$ ). To decrease the risk of clinical failure in individuals weighing $>70 \mathrm{~kg}$, the duration of treatment with $30 \mathrm{mg}$ daily can be extended to achieve a total dose of $6 \mathrm{mg} / \mathrm{kg}$, especially if the infection was acquired in an area of known tolerance to standard primaquine therapy.

Dosing should coincide with the last 2 weeks of chloroquine, mefloquine, or doxycycline prophylaxis or initiated during the final week of atovaquone-proguanil prophylaxis.

Radical cure. Primaquine used in conjunction with an effective blood stage schizonticide, such as chloroquine, for the treatment of a symptomatic patient with $P$. vivax or $P$. ovale malaria is termed radical cure. Used in this way, primaquine will prevent relapse from dormant liver stage or hypnozoite forms of $P$. vivax and $P$. ovale parasites. The doses of primaquine are the same as for PART above. If the results of G6PD testing return in time and the patient is found to be 
TABLE 1

Efficacy of primaquine for primary prophylaxis

\begin{tabular}{|c|c|c|c|c|}
\hline Country/population & Study type & Dosage/sample size (n) & $\begin{array}{l}\text { Duration of } \\
\text { prophylaxis }\end{array}$ & Efficacy $(95 \%$ CI) \\
\hline $\begin{array}{l}\text { USA/American } \\
\text { volunteers }\end{array}$ & Experimental challenge & $\begin{array}{l}15 \mathrm{mg} / \mathrm{d}(n=3) \\
30 \mathrm{mg} / \mathrm{d}(n=3) \\
45 \mathrm{mg} / \mathrm{d}(n=1)\end{array}$ & $\begin{array}{l}6 \text { days after } \\
\text { experimental } \\
\text { infection }\end{array}$ & $\begin{array}{l}\text { P. falciparum infection in: } \\
1 / 3 \text { on } 15 \mathrm{mg} / \mathrm{d} \\
0 / 3 \text { on } 30 \mathrm{mg} / \mathrm{d} \\
0 / 1 \text { on } 45 \mathrm{mg} / \mathrm{d}\end{array}$ \\
\hline $\begin{array}{l}\text { USA/American } \\
\text { volunteers }\end{array}$ & Experimental challenge & $\begin{array}{l}10 \mathrm{mg} / \mathrm{d}(n=10) \\
15 \mathrm{mg} / \mathrm{d}(n=10) \\
30 \mathrm{mg} / \mathrm{d}(n=10)\end{array}$ & $\begin{array}{l}6 \text { days after } \\
\text { experimental } \\
\text { infection }\end{array}$ & $\begin{array}{l}P . \text { vivax infection in: } \\
3 / 10 \text { on } 10 \mathrm{mg} / \mathrm{d} \\
2 / 10 \text { on } 15 \mathrm{mg} / \mathrm{d} \\
0 / 10 \text { on } 30 \mathrm{mg} / \mathrm{d}\end{array}$ \\
\hline $\begin{array}{l}\text { USA/American } \\
\text { volunteers }\end{array}$ & Experimental challenge & $30 \mathrm{mg} / \mathrm{d}(n=5)$ & $\begin{array}{l}6 \text { days following } \\
\text { experimental } \\
\text { infection }\end{array}$ & $\begin{array}{l}P \text {. falciparum infection in: } \\
0 / 5 \text { on } 30 \mathrm{mg} / \mathrm{d}\end{array}$ \\
\hline $\begin{array}{l}\text { Papua (Indonesian } \\
\text { New Guinea)/ } \\
\text { non-immune } \\
\text { migrants }^{16}\end{array}$ & $\begin{array}{l}\text { Randomized, open label } \\
\text { placebo-controlled } \\
\text { trial }\end{array}$ & $\begin{array}{l}30 \mathrm{mg} / \mathrm{d} \\
\quad(n=97)\end{array}$ & 20 weeks & $\begin{array}{l}93 \% \text { overall }(71 \%-98 \%) \\
88 \% \text { P. falciparum }(48 \%-97 \%) \\
92 \% \text { P. vivax }(37 \%-99 \%)\end{array}$ \\
\hline $\begin{array}{l}\text { Papua/non-immune } \\
\text { migrants }^{12}\end{array}$ & Non-randomized open label & $\begin{array}{l}30 \mathrm{mg} \text { every other } \\
\text { day }(n=54)\end{array}$ & 16-19 weeks & $\begin{array}{l}74 \% \text { P. falciparum } \\
90 \% \text { P. vivax }\end{array}$ \\
\hline \multirow[t]{2}{*}{ Kenya/children ${ }^{11}$} & $\begin{array}{l}\text { Randomized, placebo-controlled, } \\
\text { double-blind }\end{array}$ & $\begin{array}{l}\text { a. } 0.5 \mathrm{mg} / \mathrm{kg} 3 \mathrm{~d} / \text { week } \\
\quad(n=40)\end{array}$ & 11 weeks & $0 \%$ efficacy against $P$. falciparum \\
\hline & & $\begin{array}{l}\text { b. } 0.5 \mathrm{mg} / \mathrm{kg} / \mathrm{d} \\
\quad(n=32)\end{array}$ & 11 weeks & $\begin{array}{c}85 \%(68 \%-93 \%) P . \text { falciparum } \\
\text { parasitemia; } 83 \%(50 \%-94 \%) \\
P . \text { falciparum clinical malaria }\end{array}$ \\
\hline $\begin{array}{l}\text { Papua/non-immune } \\
\text { migrants }^{13}\end{array}$ & $\begin{array}{l}\text { Randomized, placebo-controlled, } \\
\text { double-blind }\end{array}$ & $30 \mathrm{mg} / \mathrm{d}(n=126)$ & 52 weeks & $\begin{array}{l}94.5 \%(57 \%-99 \%) P . \text { falciparum } \\
90.4 \%(58 \%-98 \%) P . \text { vivax }\end{array}$ \\
\hline $\begin{array}{l}\text { Colombia/non-immune } \\
\text { soldiers }^{14}\end{array}$ & $\begin{array}{l}\text { Randomized, placebo-controlled, } \\
\text { double-blind }\end{array}$ & $30 \mathrm{mg} / \mathrm{d}(n=122)$ & 16 weeks & $\begin{array}{l}94 \%(78 \%-99 \%) P . \text { falciparum } \\
85 \%(57 \%-95 \%) P \text {. vivax. (note: } \\
\text { counted symptomatic malaria } \\
\text { cases only, not all parasitemias) }\end{array}$ \\
\hline $\begin{array}{l}\text { Ethiopia/Israeli } \\
\text { travelers }^{19}\end{array}$ & Prospective observational & $15-30 \mathrm{mg} / \mathrm{d}(n=106)$ & $2-3$ weeks & $\begin{array}{l}5.7 \% \text { infected with malaria; } 4 P . \\
\quad \text { falciparum, } 1 P . \text { vivax }, 1 \text { both }\end{array}$ \\
\hline
\end{tabular}

G6PD normal, primaquine should be initiated to overlap with some portion of the blood stage treatment of these species.

\section{EFFICACY AND EFFECTIVENESS}

Prophylaxis (Table 1). In clinical studies using experimental challenge with infectious sporozoites, the timing of primaquine dosing proved critical to protective efficacy. Single doses of $30 \mathrm{mg}$ given during days 1 or 3 after sporozoite injection were effective in preventing malaria, but lower amounts of primaquine and any dose given before or after that window were not reliably effective ${ }^{8}$ (although very high doses, e.g., 120-180 mg, were effective when given just before challenge). ${ }^{9}$ Similarly, a single $45-\mathrm{mg}$ dose given alone or with chloroquine before or on the day of experimental challenge with $P$. falciparum did not have a causal prophylactic effect. ${ }^{10}$ For daily dosing regimens, early studies showed less than optimal efficacy at $15 \mathrm{mg} / \mathrm{d}$, whereas $30 \mathrm{mg} / \mathrm{d}$ provided good efficacy. ${ }^{2,8,10}$

More recently, a thrice weekly regimen of $15 \mathrm{mg}$ primaquine in Kenyan children showed no protective efficacy against $P$. falciparum, ${ }^{11}$ and an alternate day regimen of 0.5 $\mathrm{mg} / \mathrm{kg}$ in Indonesia proved $74 \%$ and $90 \%$ effective against $P$. falciparum and $P$. vivax, respectively. ${ }^{12}$ All of these data point to an adult regimen of $30 \mathrm{mg}$ daily for the prevention of malaria.

A number of studies conducted in the past 10 years examined daily primaquine ( $30 \mathrm{mg}$ or an $\sim 0.5-\mathrm{mg} / \mathrm{kg}$ dose in children) for primary prophylaxis in populations semi-immune and non-immune to malaria. A randomized, double-blinded placebo-controlled trial in Indonesian migrants to Papua re- ported protective efficacy of 95\% (95\% CI: 61-99\%) against P. falciparum and 90\% (95\% CI: 65-99\%) against P. vivax. ${ }^{13}$ In a randomized, placebo-controlled trial among Kenyan children, $0.5 \mathrm{mg} / \mathrm{kg} / \mathrm{d}$ was $85 \%$ (95\% CI: $68-93 \%$ ) effective for prevention of $P$. falciparum parasitemia. ${ }^{11}$ In non-immune Colombian soldiers, a randomized, double-blinded placebocontrolled trial calculated protective efficacy at 94\% (95\% CI: $78-99 \%$ ) for $P$. falciparum and 85\% (95\% CI: 57-95\%) for $P$. vivax. ${ }^{14}$ The authors of the Colombian study later combined chloroquine $300 \mathrm{mg}$ weekly with daily primaquine $(30 \mathrm{mg} / \mathrm{d})$ to "improve the efficacy of primaquine for malaria prophylaxis." 15 However, protective efficacy for the combination was not appreciably improved: $88 \%$ (95\% CI: 76-94\%) effective (89\% against $P$. falciparum and $88 \%$ against $P$. vivax). ${ }^{15}$ Another randomized placebo-controlled trial in non-immune migrants to Papua showed protective efficacy of $93 \%(95 \%$ CI: $71-98 \%$ ); $88 \%$ for $P$. falciparum and $92 \%$ for $P$. vivax. ${ }^{16}$

A limitation with each of these studies was the inability to continue follow-up after prophylaxis to look for late relapse (because the subjects lived in areas of high risk). ${ }^{17}$ However, the early experimental trials did follow subjects for many months after challenge without evidence of relapse. Arnold and others ${ }^{2}$ gave $30 \mathrm{mg}$ of primaquine to volunteers on days $-1,0$, and 1 though 6 after challenge with the Chesson strain of $P$. vivax. None of the 10 persons challenged developed vivax malaria when followed for a range of 190-450 days. This suggests that not only does primaquine have causal prophylactic activity, but that it will also prevent development of hypnozoites of $P$. vivax.

Although no severe falciparum malaria occurred among parasitemic subjects during the evaluation of primaquine pro- 
phylaxis, some authorities are concerned that severe $P$. falciparum malaria could occur if there is primaquine failure, ${ }^{18}$ because of the lack of blood schizonticidal activity of the drug against falciparum parasites.

A study reported the effectiveness of daily $15 \mathrm{mg}$ of primaquine (30 $\mathrm{mg}$ for those $>70 \mathrm{~kg}$ ) for primary prophylaxis in non-immune Israeli travelers. ${ }^{19}$ Primaquine was more effective than mefloquine or doxycycline in preventing malaria caused by $P$. vivax, with post-travel infection rates for all species of malaria $6 \%, 52 \%$, and $53 \%$, respectively. The mefloquine failures were all caused by late occurrences of $P$. vivax, and in the doxycycline group, no travelers completed the post-travel 4-week course.

Prophylaxis is not currently included as an approved labeled use of primaquine. Nonetheless, the drug offers important advantages to travelers departing on short notice or for travel that has only a brief risk (given its relatively short post-travel dosing). Unfortunately, obtaining confirmation of adequate G6PD levels in individuals before prescribing primaquine requires phlebotomy and can take up to 1 week or longer. Nevertheless, primaquine for prophylaxis in G6PDnormal, non-pregnant travelers can be recommended as an alternative when other chemoprophylactic agents are inappropriate or contraindicated. , $^{5,20}$

PART (terminal prophylaxis) and radical cure. Primaquine is usually used to prevent relapse of $P$. vivax or $P$. ovale, i.e., to kill developing or dormant liver stages of a confirmed infection (radical cure) or as presumptive therapy to prevent relapse of suspected or possible infection. The majority of $P$. vivax and $P$. ovale cases occur $>2$ months after return from travel, even in persons who take appropriate malaria chemoprophylaxis, ${ }^{21}$ and could be prevented by PART with primaquine. While there is reasonable consensus among experts that PART should be used in those with "intense" or "significant" exposure, there is no consensus as to what constitutes an intense or significant exposure. There is agreement that most travelers do not need PART because the overall risk of developing malaria caused by $P$. vivax or $P$ ovale is low, and the requirement to screen for G6PD deficiency before prescribing primaquine makes its use impractical for many travelers. PART should be considered for persons who have resided for prolonged periods (e.g., 6 months or more) in high-risk areas or who experience intense exposure to $P$. vivax such as has been described in rafters on the Omo River in Ethiopia ${ }^{19}$ or in travelers to Papua New Guinea. ${ }^{22}$

To put imported malaria into perspective, for the years 1998 through 2004, there were 9,491 cases of malaria reported in the United States; ${ }^{23-29} 4,574$ (48.2\%) of these were caused by $P$. falciparum, 2,790 were caused by $P$. vivax $(29.4 \%), 373$ $(3.9 \%)$ were caused by $P$. malariae, and $260(2.7 \%)$ were caused by $P$. ovale. In the remaining cases, the species was not determined. Of these cases, there were 38 deaths attributable to $P$. falciparum, 1 to a mixed $P$. falciparum/ $P$. malariae infection, 2 to $P$. ovale, 1 to $P$. vivax, and in 2 cases, the species could not be determined. The overall case fatality rate has been estimated by the CDC to be $0.06 \%$ for $P$. vivax, $0.3 \%$ for $P$. ovale and $P$. malariae, and $1.3 \%$ for $P$. falciparum. ${ }^{30}$

Until recently, the most widely accepted and FDAapproved regimen of primaquine in PART was $15 \mathrm{mg}$ daily for 14 days. ${ }^{31,32}$ An alternative regimen of $30 \mathrm{mg}$ daily for 14 days had been used when so-called "tolerant" strains of $P$. vivax (mostly from Southeast Asia or Oceania) were sus- pected. ${ }^{31}$ While certain strains of $P$. vivax have been termed primaquine-tolerant or -resistant (i.e., not eradicated by the 15-mg dose), it is more likely that these strains represent $a$ priori biologic differences in sensitivity to primaquine rather than true development of tolerance or resistance to primaquine.

From the beginning of experimental work using the Chesson strain of $P$. vivax (isolated from an American soldier in New Guinea during the Second World War) ${ }^{33}$ and the St. Elizabeth strain of $P$. vivax (from temperate United States), a marked difference in response to primaquine was observed. ${ }^{34-36}$ For elimination of the Chesson strain, a dose of 22.5 to $30 \mathrm{mg} / \mathrm{d}$ of primaquine for 14 days was required; 15 $\mathrm{mg} / \mathrm{d}$ was not effective. ${ }^{34,37}$ However, $15 \mathrm{mg} / \mathrm{d}$ of primaquine for 14 days eliminated the St. Elizabeth strain and later the Korean strain in US service personnel during the Korean War, although treatment of the Korean strain was always combined with chloroquine. ${ }^{35,36}$ The decision to use $15 \mathrm{mg} / \mathrm{d}$ for 14 days in the early 1950s was based on the need for a dose that could be given safely to returning Korean War African American soldiers. Individuals of African descent have a higher likelihood of G6PD deficiency than most groups of whites, although their G6PD impairment tends to be mild. With the finding that the hemolytic anemia induced by primaquine was usually dose dependent, $15 \mathrm{mg} / \mathrm{d}$ was chosen as a dose that could be given to all US service personnel without concern that there would life-threatening hemolysis in the African-American soldiers (see section on Safety/Tolerability).

FDA licensure of primaquine in 1952 was based on the need to prevent relapsing $P$. vivax malaria in returning Korean war veterans, the finding from clinical trials establishing that the $15-\mathrm{mg}$ daily dose could be safely given without medical supervision to African Americans who might develop hemolytic anemia with higher doses of primaquine and the knowledge that $15 \mathrm{mg}$ daily for 14 days was efficacious against Korean strains of $P$. vivax. ${ }^{34,36,38,39}$ Therefore, safety concerns, rather than efficacy against all strains of $P$. vivax, led to the licensure of the $15 \mathrm{mg}$ daily for a 14-day regimen.

It is important to recognize that chloroquine or quinine have been shown to be required for the therapeutic efficacy of primaquine for the eradication of the hypnozoite once it has been established. ${ }^{37}$ In a remarkable series of experimental infections with the Chesson strain of $P$. vivax, $15 \mathrm{mg}$ daily for 14 days of primaquine when given 2 days after completion of a curative course of quinine (a short-acting drug) for the initial blood stage infection led to a cure rate of only $21 \%(4 / 19$; 15 relapsed between 32 and 92 days). When the same regimen of primaquine was given concurrently with quinine or chloroquine, cure was seen in $95 \%(18 / 19)$ and $74 \%(14 / 19)$, respectively. These data generated 50 years ago require additional investigation, but practically, primaquine may exert its beneficial effect for PART or radical cure when combined with a 4-amino-quinoline drug such as chloroquine. Importantly, the mass administration of primaquine to returning Korean War veterans during the 1951-1952 trans-Pacific crossings was always accompanied by chloroquine. At the time, the thinking was to give chloroquine for the residual blood stages and primaquine for the hypnozoite. Two drugs were being administered for two indications with no thought of potentiation or synergy. This potential for synergy has 
never been studied for primaquine with mefloquine, doxycycline, or atovaquone/proguanil.

Failure of standard primaquine therapy (15 mg daily for 14 days) to prevent relapse has been reported from the Solomon Islands, ${ }^{40-43}$ Southeast Asia, ${ }^{44-48}$ Brazil $^{49-51}$ Colombia, ${ }^{52}$ Guyana, ${ }^{53}$ Guatemala, ${ }^{54}$ Somalia, ${ }^{55}$ Ethiopia, ${ }^{56,57}$ Afghani$\operatorname{stan}^{58,59}$ and elsewhere. ${ }^{22,60-64}$ Because supervised compliance was not confirmed in these studies, these reports may not all represent failures of the $15-\mathrm{mg} / \mathrm{d}$ regimen. As examples, among US troops in Somalia who took PART, $43 \%$ relapsed, but compliance was not supervised and was selfreported, ${ }^{55}$ and in a cohort of US soldiers with $P$. vivax malaria from Afghanistan, only 38\% were compliant with PART. ${ }^{59}$ Although a study from the Solomon Islands found no relapse during 1 year of follow-up subsequent to treatment with either a 15- or 22.5-mg daily regimen of primaquine, ${ }^{65} \mathrm{a}$ regimen of $22.5 \mathrm{mg}$ daily was superior to the $15-\mathrm{mg}$ regimen in Thailand. ${ }^{47}$ Based on these findings as well as detailed clinical studies of the Chesson strain of $P$. vivax, experts have recommended the $30-\mathrm{mg}$ adult daily regimen for radical cure of $P$. vivax malaria acquired in Southeast Asia or Oceania. ${ }^{48,66,67}$ Last, there was a higher risk of relapse after standard primaquine therapy (equivalent to $15 \mathrm{mg}$ daily) among subjects weighing $>70 \mathrm{~kg}$, and higher doses equivalent to the 30-mg daily regimen of primaquine have been recommended for such individuals. ${ }^{51,56,68}$

After assessment of these clinical studies and the historical findings of a variable response to the $15-\mathrm{mg}$ daily dose, the $\mathrm{CDC}$ has now recommended that $30 \mathrm{mg} / \mathrm{d}$ for 14 days be the standard dose for PART and radical cure. ${ }^{5}$ Because of the possibility of decreased effectiveness in persons $>70 \mathrm{~kg}$ because of sub-therapeutic dosing, clinicians can consider extending the duration of PART in these individuals beyond 14 days targeting a total dose of $6 \mathrm{mg} / \mathrm{kg} .{ }^{67}$ A daily dose of $>30$ $\mathrm{mg}$ is not recommended because the safety of higher daily doses is not proven.

To avoid drug-induced hemolysis, a regimen of $45 \mathrm{mg}$ weekly (adult dose) for 8 weeks has been considered when a person has partial G6PD deficiency. ${ }^{40,69}$ Both the 45 - and $30-\mathrm{mg}$ regimens have proven to be effective treatment against strains of $P$. vivax that were not killed by standard therapeutic regimens. ${ }^{18,34,42,70}$ The alternative dosing regimen of $45 \mathrm{mg}$ primaquine once weekly combined with weekly chloroquine for 8 weeks was introduced in the early 1960s by the US military. ${ }^{40}$ Weekly dosing made supervised therapy feasible and improved compliance over the standard primaquine regimen given daily for 14 days. Studies performed in persons known to be moderately G6PD-deficient showed that the 45mg weekly dose could be given with acceptable toxicity, although the data is limited and clinically apparent hemolytic anemia was seen. These observations evolved to a recommendation that the weekly dosing could be given to those who are G6PD-deficient. However, this weekly dosing regimen is not FDA approved, the data to support efficacy are limited, and safety data in G6PD-deficient persons, especially in those who have other than the mild, A-phenotype, are not known. Primaquine for PART in a known G6PD-deficient individual is not recommended. Use of primaquine for radical cure in a known G6PD-deficient individual should be used only after a careful risk/benefit assessment and under strict medical supervision.

A shortened course of primaquine for radical cure would improve effectiveness (lower cost, greater availability, greater compliance). ${ }^{71}$ Earlier non-controlled studies reported that primaquine $15 \mathrm{mg}$ daily for 5 days was effective in preventing $P$. vivax relapse. ${ }^{72-74}$ However, controlled studies have shown $15 \mathrm{mg}$ daily for 5 days has no therapeutic efficacy and, therefore, this duration of treatment should not be used. ${ }^{75-79}$

If a dose of primaquine is missed during PART, the course should be continued until all doses are taken (B-III). Because total cumulative dose is important in determining efficacy of primaquine treatment, ${ }^{68}$ it is not necessary to restart PART.

\section{PHARMACOKINETICS}

In five fasted, healthy volunteers who were given oral primaquine along with an intravenous dose of radiolabeled primaquine, absorption was nearly complete, ${ }^{80,81}$ with a mean bioavailability of $96 \%{ }^{80}$ Areas under the concentration curve after doses of 15, 30, and $45 \mathrm{mg}$ were linear, suggesting firstorder kinetics. The mean $t_{\max }$ was $3 \pm 1$ hours (2- to 3 -hour range) in healthy volunteers given a $45-\mathrm{mg}$ dose. The mean $\mathrm{C}_{\max }$ in these subjects was $153 \pm 24 \mathrm{ng} / \mathrm{mL}$ (range, 131-180 $\mathrm{ng} / \mathrm{mL}$ ). In Thai volunteers given a 14-day regimen of primaquine, there was no difference in $\mathrm{t}_{\max }$ and $\mathrm{C}_{\max }$ after the first and last doses. ${ }^{82}$ Among Indian patients being treated for $P$. vivax malaria, the mean $\mathrm{t}_{\max }$ and $\mathrm{C}_{\max }$ were similar to values in healthy subjects. ${ }^{83}$

Primaquine is extensively distributed in tissues, with the mean apparent volume of distribution ranging from 200 to 300 L. ${ }^{80,83,84}$ Unlike chloroquine, primaquine does not accumulate in red blood cells. In one study, the mean whole blood to plasma concentration ratio of primaquine was $0.81{ }^{80}$ Primaquine binds preferentially to the acute phase reactant protein alpha-1-glycoprotein, and the amount of that protein in blood may alter the distribution of free primaquine. ${ }^{85}$

The metabolism of primaquine in humans and various animal systems has been reviewed. ${ }^{86}$ In human microsomes in vitro, primaquine was metabolized primarily to carboxyprimaquine..$^{80,87,88}$ The time to peak carboxyprimaquine levels in plasma was 3-12 hours, with the $\mathrm{C}_{\max }$ being 10 times higher than the parent compound. Carboxyprimaquine does not accumulate during 14 days of dosing. Primaquine is also metabolized to a number of other identified and unidentified metabolites that are detectable in urine and plasma. Only $\sim 1-4 \%$ of primaquine is eliminated as parent compound in urine..$^{80,89}$

Primaquine has been shown to decrease the clearance of antipyrene, resulting in an increase in its half-life. ${ }^{90}$ Antipyrene is a general probe for the hepatic cytochrome P-450 (CYP) ${ }^{91}$ If there is no change in antipyrene metabolism with the drug of interest, there are likely to be no significant CYP interactions. Recent studies show that primaquine induces the CYP 1A2 enzyme in both recombinant and microsomal in vitro systems..$^{87,92,93}$ This induction could decrease the plasma concentrations of drugs that are metabolized by CYP 1A2, with a potential for decreased efficacy. ${ }^{94,95}$ Examples of commonly prescribed drugs that are metabolized by CYP 1A2 are tricyclic antidepressants; antipsychotics (e.g., clozapine and haloperidol); and benzodiazepines, caffeine, propranolol, theophylline, and warfarin (http://medicine.iupui.edu/flockhart/ table.htm). The clinical significance of this potential interac- 
tion is not known; however, prescribing primaquine for prophylaxis concurrently with drugs that are metabolized by CYP 1A2, warfarin should be undertaken with caution or avoided. Because there is no other drug for PART or radical cure, clinicians should weigh the risks and benefits of using primaquine. Mefloquine inhibits metabolism of primaquine (and vice versa) in an in vitro microsome system, but the clinical relevance of this interaction is not known. ${ }^{96}$

In healthy volunteers, the half-life (elimination) of primaquine was $7 \pm 4$ hours (2- to 12 -hour range). ${ }^{84}$ In another study, it was $6 \pm 2$ hours. ${ }^{80}$ In healthy Thai volunteers, it was $4 \pm 1$ hours after a 14-day dosing. ${ }^{82}$ Similar estimates were observed in patients with $P$. vivax malaria and in those with G6PD deficiency. ${ }^{83}$

Although liver or renal disease could theoretically delay metabolism or excretion of primaquine, ${ }^{97}$ there are no data available to suggest optimal dosing adjustments in individuals with hepatic or renal dysfunction. Current recommendations are to not change dosing of primaquine in patients with renal insufficiency or renal failure. ${ }^{98}$

Virtually all pharmacokinetic studies of primaquine have been conducted on fasted human subjects. Little is known of the effect of food on primaquine, with the exception of the apparent ability of food to greatly diminish the risk of gastrointestinal upset. In an uncontrolled study involving subjects who were fed 15 minutes after primaquine dosing, ${ }^{99}$ the $\mathrm{C}_{\max }$ and area under the curve for primaquine were substantially higher in fed subjects compared with subjects with malaria or healthy Thai or white subjects. Randomized studies of primaquine pharmacokinetics in fed versus fasted subjects are needed. Nonetheless, most authorities recommend that primaquine be administered with food or after a meal to avoid gastrointestinal adverse events, especially abdominal cramps. $^{38,97,100}$

\section{COMPLIANCE}

No published study has examined compliance with a daily regimen of primaquine for prophylaxis. Studies of suppressive prophylaxis using other anti-malarials reveal that individuals are frequently non-compliant with doses that should be taken after leaving the malarious area. ${ }^{101-103}$ Full compliance with the 2-week regimen of PART with primaquine in repatriated military populations has ranged from $4 \%$ to $80 \% .{ }^{104-106}$ The requirement for only 1 week of post-exposure prophylaxis when primaquine is used for primary prophylaxis should improve patient compliance. Given the importance of dosing within 24-72 hours after challenge (described previously), ${ }^{8}$ compliance with daily dosing of primaquine may prove an important determinant of effectiveness, especially in areas of very high risk. ${ }^{107}$

\section{SAFETY/TOLERABILITY}

The most serious adverse event linked to primaquine is an acute intravascular hemolysis in people having an inborn deficiency of G6PD. ${ }^{108}$ The most common adverse event in G6PD-normal, non-pregnant individuals is gastrointestinal upset if primaquine is ingested on an empty stomach. ${ }^{13} \mathrm{~A}$ mild, self-limited, and asymptomatic methemoglobinemia oc- curs in most people receiving primaquine. Clinical studies of subjects receiving therapeutic or prophylactic regimens do not corroborate early studies suggesting that primaquine causes cellular immune suppression and leucopenia.

G6PD deficiency. Primaquine causes hemolytic anemia in people with an inborn deficiency of G6PD. The severity of hemolytic anemia seems to be related to primaquine dosing and the variant of the G6PD enzyme, i.e., the degree of G6PD deficiency. More than 300 allelic variants are known. These are divided into classes based on level of residual enzyme activity in red blood cells. ${ }^{108}$ The most common variant occurs in persons of African descent $\left(\mathrm{A}^{-}\right)$who have a mild impairment of G6PD activity (usually $>10 \%$ activity), and in whom primaquine causes a mild hemolytic anemia limited to senescent red blood cells. ${ }^{109}$ Other ethnic groups, including whites and Asians, may have a more severe form of G6PD deficiency (typically $<10 \%$ residual activity) that can result in progressive, potentially fatal hemoglobinemia and hemoglobinuria after treatment with standard doses of primaquine. ${ }^{97}$ Prevalence of G6PD deficiency is relatively common among Africans (1-20\%) and typically rare in other ethnic groups $(<1 \%)$.

In persons with normal levels of G6PD, hemolysis is not observed. One study reported no noticeable hemolysis among Thai patients with normal levels of G6PD taking $22.5 \mathrm{mg}$ of primaquine daily for 14 days. ${ }^{47}$ The same was true among 99 G6PD-normal Javanese adults receiving $30 \mathrm{mg}$ primaquine daily for 20 weeks. $^{16}$

In persons with mild impairment of G6PD activity, hemolysis starts 3-4 days after the first dose of primaquine and lasts $\sim 7$ days. Recovery with reticulocytosis occurs even if $30 \mathrm{mg}$ primaquine daily dosing is continued because reticulocytes and the remaining red cells are relatively resistant to primaquine-induced hemolysis. ${ }^{40}$

A 45-mg weekly dose of primaquine does not cause clinically significant hemolysis in people having the $\mathrm{A}^{-}$variant, and this was the basis for developing the $45 \mathrm{mg} / \mathrm{wk}$ for 8 weeks regimen for prevention of relapse. ${ }^{40}$ Eight subjects with the $\mathrm{A}^{-}$variant were administered $45 \mathrm{mg}$ weekly for 8 weeks and developed only mild, asymptomatic hemolysis (hemoglobin decrease range, $0.5-2.5 \mathrm{~g} / \mathrm{dL}) .{ }^{110}$

Investigators in Burma treated 20 patients who were hemizygous for mild deficiency and 2 patients hemizygous for severe deficiency with either one dose of primaquine $(45 \mathrm{mg}$; 9 patients with mild deficiency and 1 severe) or $45 \mathrm{mg}$ of primaquine weekly for 8 weeks (11 mild deficiency and 1 severe). ${ }^{69}$ Although the numbers were small, they found no significant change in methemoglobinemia compared with the patients with normal G6PD levels and no clinical signs of drug-induced hemolysis. In a clinical trial involving seven G6PD-deficient Thai soldiers (with variable residual enzyme activity), hemolysis after a single dose of $45 \mathrm{mg}$ primaquine was mild and affected $8-18 \%$ of red cells. ${ }^{111}$ However, severe hemolysis has been reported after the administration of a single 45-mg dose in whites ${ }^{112}$ and in patients in Vanuatu with severe deficiency. ${ }^{113}$

The degree of hemolysis in other variants of G6PD exposed to standard primaquine therapy (15-30 mg daily) varies widely. In Burma, two healthy volunteers infused with G6PDdeficient red blood cells and given $15 \mathrm{mg}$ daily for 14 days lost $34-48 \%$ of those cells. ${ }^{114}$ Among 441 patients treated with primaquine (15 mg/d for 14 days) for $P$. vivax in Thailand, 13 
were G6PD-deficient. ${ }^{115}$ These patients developed only slightly lower hematocrits. Primaquine induced hemolysis in three other Thai subjects $(29 \%$ residual activity in one and $2-10 \%$ in the other two), with their hematocrits decreasing by 9-13\%. ${ }^{116}$

The Mediterranean $\mathrm{B}^{-}$variant of G6PD deficiency occurs in individuals whose ethnic background includes ancestors from the Mediterranean basin or west Asia. Individuals with the $\mathrm{B}^{-}$variant have minimal or no detectable residual G6PD enzyme activity. ${ }^{97,117}$ Administration of primaquine to people with the $\mathrm{B}^{-}$variant risks severe, potentially life-threatening hemolysis. A randomized, open-label trial in Malaysian Borneo compared chloroquine, chloroquine-primaquine, and pyrimethamine-sulfadoxine for treatment of individuals with acute malaria. Sixteen subjects with severe G6PD deficiency were unwittingly treated with chloroquine-primaquine $(1.5 \mathrm{~g}$ chloroquine and $15 \mathrm{mg} / \mathrm{d}$ primaquine for 3 days for $P$. falciparum infection or for 14 days for $P$. vivax infection). Seven subjects experienced hemolytic anemia, and five of them required transfusion with one to two units of blood. Among the transfused subjects, two suffered renal failure, with one requiring peritoneal dialysis. ${ }^{118}$ Severe hemolysis with renal failure requiring dialysis was reported in a Thai soldier after three $15-\mathrm{mg}$ doses of primaquine. ${ }^{119}$ Severe hemolysis occurred among G6PD-deficient Sardinians given a single dose of $30 \mathrm{mg}$ primaquine. ${ }^{120}$

Because of the risk of hemolysis in G6PD-deficient individuals, laboratory determination of the patient's G6PD status must be performed before prescribing primaquine. This can be done with either a quantitative determination of the enzyme level or a qualitative screening test. ${ }^{121}$ Quantitative assays will identify nearly all persons with a G6PD deficiency; however, they are more expensive to perform and are not necessary to obtain for the purposes of determining whether primaquine may be safely administered. Qualitative screening tests are sufficient to identify individuals with a G6PD deficiency with the following exceptions: recent hemolysis in a person with one of the milder G6PD deficiency variants and some women who are heterozygous for the gene and have mild deficiency. In cases of primaquine-induced hemolysis, older erythrocytes are selectively hemolyzed, leaving younger cells with near normal levels of G6PD. ${ }^{108,121}$ Nevertheless, qualitative tests will identify persons who will be at risk from taking primaquine, and if the test is abnormal, the drug should not be used for prophylaxis.

Persons deficient in the enzyme NADH methemoglobin reductase are extremely sensitive to hemoglobin-oxidizing agents such as primaquine. ${ }^{122,123}$ This enzymatic deficiency is much rarer than G6PD deficiency and is associated with methemoglobinemia.

Methemoglobinemia. Methemoglobinemia (> 1\% methemoglobin) usually occurs with therapeutic or prophylactic dosing regimens. One study reported mean/maximum methemoglobin levels of $6 \% / 9 \%, 10 \% / 18 \%$, and $11 \% / 18 \%$ among persons receiving $15,22.5$, and $30 \mathrm{mg}$ of primaquine, respectively, for 14 days. ${ }^{38}$ Another study $(N=30)$ of primaquine (15 mg for 14 days) reported mean methemoglobin levels of $5.9 \%$ (range, $1.3-19.3 \%$ ) at 14 days; there were no reported symptoms relating to the methemoglobinemia. ${ }^{124}$ Two weeks after the last dose, the highest methemoglobin level (19.3\%) decreased to $2.3 \%$. In other studies, methemoglobin levels as high as $18 \%$ have been reported among persons taking 22.5 mg daily for 14 days, ${ }^{125}$ and in persons in a 20 -week trial, the highest methemoglobin level recorded on the last day of prophylaxis was $8.5 \%{ }^{16}$ In this latter study, the authors determined that the risk of methemoglobinemia did not increase with the duration of administration of primaquine and that it resolved within 2 weeks after cessation of dosing. ${ }^{16}$ Among persons taking $0.5 \mathrm{mg} / \mathrm{kg} / \mathrm{d}$ (adult dose equivalent $30 \mathrm{mg} / \mathrm{d}$ ) primaquine for 1 year, no negative impact on the complete blood count or renal or hepatic function was seen; methemoglobinemia levels at week 50 ranged from $1.4 \%$ to $13 \%$ (mean, $5.8 \%)^{13}$

Cyanosis can occur when the methemoglobin level exceeds $15-20 \mathrm{~g} / \mathrm{L}$ of blood ( $10 \%$ of the normal level of hemoglobin),${ }^{97}$ although cyanosis may be seen in fair-skinned persons at methemoglobin levels of $<6 \% .{ }^{122}$ The clinical use of specific methemoglobinemia percentages is unclear. In some studies, methemoglobinemia values of up to $20 \%$ are often asymptomatic $^{126}$ and may be well-tolerated up to levels of $25 \% .{ }^{97}$ Most authorities have argued that, whereas patients tolerate levels $<10 \%$ quite well, persons with levels of $20 \%$ are likely to be symptomatic. Others suspect that the presence or absence of symptoms depends not just on absolute percentage of methemoglobinemia, but also the rapidity with which methemoglobinemia occurs. ${ }^{122}$

Symptoms may develop at lower methemoglobin levels in persons with underlying pulmonary disease and limited pulmonary reserve. ${ }^{127}$ No study has documented clinically apparent methemoglobinemia after therapeutic or prophylactic regimens of primaquine, except in patients having an inborn deficiency of methemoglobin reductase. ${ }^{97,124}$ In summary, primaquine-induced methemoglobinemia, although almost universal with clinical doses, seems to be mild, self-limited, and tolerated without symptoms or signs of cyanosis in otherwise healthy people.

Gastrointestinal adverse events. The risk of ADRs with primaquine increases with increasing doses of the drug (Tables 2 and 3). ${ }^{97}$ In a large study $(N=699)$ evaluating doses of 15 $\mathrm{mg} / \mathrm{d}$ or less of primaquine in adults, ADRs occurred no more frequently than with placebo. ${ }^{38}$ Among fasted persons receiving $22.5-30 \mathrm{mg} / \mathrm{d}, 10-12 \%$ reported mild to moderate abdominal cramps. ${ }^{38}$ Individuals taking $120 \mathrm{mg}$ daily reported moderate abdominal cramps and nausea. ${ }^{34}$ Administration of 240 $\mathrm{mg} / \mathrm{d}$ resulted in moderate to intolerably severe abdominal cramps. ${ }^{34}$ These early investigators noted that the risk of gastrointestinal upset at any dose of primaquine essentially disappeared when the drug was administered with food. ${ }^{38}$

A randomized, double-blind placebo-controlled trial giving fed adult subjects $30 \mathrm{mg}$ daily for 1 year found no difference in the number or type of complaints between subjects receiving primaquine compared with those receiving placebo. ${ }^{13} \mathrm{Fed}$ Kenyan children dosed with $15 \mathrm{mg}$ daily for 11 weeks tolerated primaquine as well as placebo. ${ }^{11}$ Primaquine $(0.5 \mathrm{mg} / \mathrm{kg}$ dose) for 18-20 weeks given every other day with a snack resulted in fewer ADRs than weekly chloroquine $5 \mathrm{mg} / \mathrm{kg}$ (300 $\mathrm{mg}$ in an adult) among Javanese children and adults in Papua. ${ }^{100}$ In another randomized, placebo-controlled trial in Indonesian adults, only headache, cough, and sore throat were reported significantly more frequently in recipients of primaquine compared with those taking placebo. ${ }^{16}$ Among 122 Colombian soldiers, epigastric pain, abdominal pain, and other gastrointestinal symptoms occurred among nine recipients $(7.4 \%)$ of primaquine (30 mg daily) compared with 1 of 
TABLE 2

Severe ADRs associated with primaquine use

\begin{tabular}{|c|c|c|c|c|c|}
\hline Study location/design & $\begin{array}{c}\text { Duration of } \\
\text { dosing }\end{array}$ & Dosing regimen & $\begin{array}{l}\text { Number of severe } \\
\text { ADRs/number at risk }\end{array}$ & Adverse event & $\begin{array}{l}\text { Discontinued because } \\
\text { of severe ADRs }\end{array}$ \\
\hline USA/experimental challenge ${ }^{34}$ & $14 \mathrm{~d}$ & $15-240 \mathrm{mg} / \mathrm{d}$ & - & Abdominal cramping & NA \\
\hline USA/experimental challenge ${ }^{38}$ & $6-14 \mathrm{~d}$ & $15-120 \mathrm{mg} / \mathrm{d}$ & $0 / 89$ & None & None \\
\hline USA/experimental challenge ${ }^{67}$ & $7 \mathrm{~d}$ & $60 \mathrm{mg} / \mathrm{d}$ & $1 / 11$ & $\begin{array}{l}\text { Abdominal cramping, } \\
\text { vomiting, cyanosis }\end{array}$ & $\begin{array}{l}\text { SADR attributed to } \\
\text { another substance } \\
\text { in } 1 \text { subject }\end{array}$ \\
\hline Papua/randomized placebo-controlled ${ }^{16}$ & $20 \mathrm{wk}$ & $30 \mathrm{mg} / \mathrm{d}$ & $0 / 97$ & None & None \\
\hline $\begin{array}{l}\text { Papua/randomized double blind, } \\
\text { placebo-controlled }{ }^{13}\end{array}$ & $52 \mathrm{wk}$ & $30 \mathrm{mg} / \mathrm{d}$ & $0 / 126$ & None & None \\
\hline $\begin{array}{l}\text { Kenya/randomized double-blind, } \\
\text { placebo-controlled }\end{array}$ & $11 \mathrm{wk}$ & $15 \mathrm{mg} / \mathrm{d}$ & $0 / 32$ & None & None \\
\hline $\begin{array}{l}\text { Colombia/randomized, double-blind, } \\
\text { placebo-controlled }^{14}\end{array}$ & $16 \mathrm{wk}$ & $30 \mathrm{mg} / \mathrm{d}$ & $3 / 122$ & $\begin{array}{l}\text { Epigastric pain, } \\
\text { vomiting, abdominal } \\
\text { pain }\end{array}$ & $3 \%$ \\
\hline Ethiopia/prospective observational ${ }^{19}$ & $2-3 w k$ & $15-30 \mathrm{mg} / \mathrm{d}$ & $1 / 106$ & Nausea, vomiting & $1 \%$ \\
\hline Papua/open clinical trial ${ }^{100}$ & $16-19 \mathrm{wk}$ & $\begin{array}{l}0.5 \mathrm{mg} / \mathrm{kg} \text { every } \\
\text { other day }\end{array}$ & $0 / 45$ & None & None \\
\hline $\begin{array}{l}\text { Thailand/open randomized clinical } \\
\text { trial }^{47}\end{array}$ & $14 \mathrm{~d}$ & 15 or $22.5 \mathrm{mg} / \mathrm{d}$ & $0 / 167$ & None & None \\
\hline $\begin{array}{l}\text { Colombia/randomized, double-blind } \\
\text { placebo-controlled }^{14}\end{array}$ & $17 \mathrm{wk}$ & $\begin{array}{l}\text { Primaquine } 30 \\
\mathrm{mg} / \mathrm{d}+300 \mathrm{mg} \\
\text { chloroquine/wk }\end{array}$ & $2 / 100$ & Vomiting & $2 \%$ \\
\hline
\end{tabular}

ADRs, adverse drug reactions; NA, not available.

54 subjects receiving placebo $(1.9 \% ; P=$ not significant $) .{ }^{14}$ Taken with a snack or meal, daily primaquine for prophylaxis $(0.5 \mathrm{mg} / \mathrm{kg} / \mathrm{d})$ seems to be as well tolerated as placebo.

Neuropsychiatric adverse events. Psychomotor effects have not been noted, ${ }^{128}$ and neuropsychiatric changes seem to be rare, with only a single case report of depression and psychosis after primaquine use. ${ }^{129}$

Immune effects. Laboratory studies suggest that primaquine inhibits lymphocyte proliferative responses in vitro. ${ }^{130,131}$ These findings served as the basis of warnings that primaquine therapy may be linked to clinically significant immunosuppression. ${ }^{97}$ Although inhibition of lymphocyte proliferation has been observed in vitro, ${ }^{132}$ in vivo studies in mice $^{133}$ and monkeys did not disclose similar findings. ${ }^{132,134}$ Primaquine did not inhibit human natural killer cell toxicity in vitro. ${ }^{135}$ Moreover, clinical studies do not corroborate immunosuppression by primaquine. In subjects receiving primaquine, Fryauff and others ${ }^{136,137}$ showed normal to elevated cellular immune responses to tetanus toxin epitopes and humoral immune responses to tetanus-diphtheria vaccine. Repeated testing of lymphocyte function during a year-long chemoprophylaxis trial produced no evidence of immune suppression or disturbance induced by moderate or long-term daily primaquine. ${ }^{138,139}$ Moreover, long-term use of primaquine did not effect intestinal helminth and protozoal parasite burdens. ${ }^{140}$

An early report linked neutropenia to a 2 -week course of primaquine therapy (dose not stated) among patients with rheumatoid arthritis. ${ }^{141}$ However, none of 338 men given 15$30 \mathrm{mg}$ of primaquine daily for 14 days showed evidence of leucopenia; $6 \%, 21 \%$, and $4 \%$ of subjects who received primaquine $15,22.5$, and $30 \mathrm{mg}$, respectively developed leukocytosis $\left(10,000-17,000 \mathrm{WBC} / \mathrm{mm}^{3}\right) .{ }^{38}$ Other investigators have also observed leukocytosis ${ }^{42}$ or no alteration in white cell counts. ${ }^{39,142}$ High-dose primaquine (120-240 mg daily) has been associated with neutropenia. ${ }^{34,38,142}$ Based on this information, some authors have advised against its use in per- sons being treated with myelosuppressive drugs or who suffer from concurrent conditions characterized by bone marrow depression. ${ }^{97}$ However, more recent clinical trials using prolonged daily primaquine dosing that included monitoring of complete blood counts (as well as hepatic and renal function testing) showed no evidence of toxicity. ${ }^{13,16}$

\section{CONTRAINDICATIONS}

Primaquine is contraindicated for prophylaxis in all persons with G6PD deficiency and in pregnant women (because of the risk of acute hemolysis in the fetus with unknown G6PD status). The packaging label states that primaquine is also contraindicated in persons with illnesses manifest by a tendency to granulocytopenia, e.g., lupus erythematosus and rheumatoid arthritis (although the rationale for this warning is suspect; see discussion above). The label further warns against concurrent treatment with other potentially hemolytic drugs or depressants of the myeloid elements of the bone marrow. ${ }^{143}$ The label warns that quinacrine hydrochloride potentiates the toxicity of primaquine, and these drugs should not be administered together.

Persons deficient in the enzyme NADH methemoglobin reductase are extremely sensitive to hemoglobin-oxidizing agents such as primaquine. ${ }^{122,123}$ Individuals with minimal cardiopulmonary reserve may poorly tolerate the methemoglobinemia induced by primaquine. Persons allergic to iodoquinol, a chemically related 8 -aminoquinolone, may be allergic to primaquine. ${ }^{144}$

\section{DURATION OF USE}

Few studies have examined the long-term use of primaquine for prophylaxis. One study reported administration of $0.5 \mathrm{mg} / \mathrm{kg}$ daily for 52 weeks with no long-term toxicity detected. ${ }^{13}$ Similar results were reported in studies that evalu- 
TABLE 3

Mild to moderate ADRs associated with primaquine use

\begin{tabular}{|c|c|c|c|c|}
\hline Study location/design & Sample size dose duration & Most frequent ADRs & Comparator & ADR risk with primaquine use \\
\hline $\begin{array}{l}\text { USA/experimental } \\
\text { challenge }\end{array}$ & $\begin{array}{l}N=45 \\
15-240 \mathrm{mg} / \mathrm{d} \\
1-14 \mathrm{~d}\end{array}$ & $\begin{array}{l}\text { Abdominal cramping, } \\
\text { anorexia, nausea, } \\
\text { vomiting }\end{array}$ & None & $\begin{array}{l}\text { In fasted subjects, risk } \\
\text { related to dose. } \\
\text { In fed subjects, no GI } \\
\text { complaints }\end{array}$ \\
\hline $\begin{array}{l}\text { USA/experimental } \\
\text { challenge }^{38}\end{array}$ & $\begin{array}{l}N=89 \\
15-120 \mathrm{mg} / \mathrm{d} \\
6-14 \mathrm{~d}\end{array}$ & $\begin{array}{l}\text { Abdominal cramping: } \\
15 \mathrm{mg}-0 \% \\
22.5 \mathrm{mg}-7 \% \\
30 \mathrm{mg}-4 \% \\
60 \mathrm{mg}-33 \% \\
120 \mathrm{mg}-100 \%\end{array}$ & None & $\begin{array}{l}\text { In fasted subjects, risk } \\
\text { related to dose }\end{array}$ \\
\hline $\begin{array}{l}\text { USA/experimental } \\
\text { challenge }\end{array}$ & $\begin{array}{l}N=11 \\
60 \mathrm{mg} / \mathrm{d} \\
7 \mathrm{~d}\end{array}$ & $\begin{array}{l}\text { Nausea, abdominal } \\
\text { cramping }\end{array}$ & None & $\begin{array}{l}2 \text { subjects with moderate } \\
\text { ADRs }\end{array}$ \\
\hline $\begin{array}{l}\text { Papua/randomized } \\
\text { placebo-controlled }^{16}\end{array}$ & $\begin{array}{l}N=97 \\
30 \mathrm{mg} / \mathrm{d} \\
20 \mathrm{wk}\end{array}$ & $\begin{array}{l}\text { Headache, abdominal } \\
\text { pain, cough, nausea, } \\
\text { dizziness }\end{array}$ & Placebo & None higher than placebo \\
\hline $\begin{array}{l}\text { Papua/randomized } \\
\text { double-blind, } \\
\text { placebo-controlled }^{13}\end{array}$ & $\begin{array}{l}N=126 \\
30 \mathrm{mg} / \mathrm{d} \\
52 \mathrm{wk}\end{array}$ & $\begin{array}{l}\text { Headache, abdominal } \\
\text { pain, URI symptoms, } \\
\text { itching/rash, fatigue }\end{array}$ & Placebo & $\begin{array}{l}\text { Cough and itch higher than } \\
\text { placebo }\end{array}$ \\
\hline $\begin{array}{l}\text { Kenya/randomized } \\
\text { double-blind, } \\
\text { placebo-controlled }^{11}\end{array}$ & $\begin{array}{l}N=32 \\
15 \mathrm{mg} / \mathrm{d} \\
11 \mathrm{wk}\end{array}$ & $\begin{array}{l}\text { Headache, abdominal } \\
\text { pain, fever, nausea, } \\
\text { diarrhea }\end{array}$ & $\begin{array}{l}\text { Placebo, mefloquine, } \\
\text { doxycycline, chloroquine } \\
\text { + proguanil }\end{array}$ & None higher than placebo \\
\hline $\begin{array}{l}\text { Colombia/randomized, } \\
\text { double-blind } \\
\text { placebo-controlled }^{14}\end{array}$ & $\begin{array}{l}N=122 \\
30 \mathrm{mg} / \mathrm{d} \\
16 \mathrm{wk}\end{array}$ & Gastrointestinal & Placebo & $\begin{array}{l}7.5 \% \text { primaquine vs. } 2 \% \\
\text { placebo }\end{array}$ \\
\hline $\begin{array}{l}\text { Ethiopia/prospective } \\
\text { observational }^{19}\end{array}$ & $\begin{array}{l}N=106 \\
30 \mathrm{mg} / \mathrm{d} \\
2-3 \mathrm{wk}\end{array}$ & Vomiting & Mefloquine, doxycycline & $\begin{array}{l}1 \text { of } 106 \text { subjects discontinued } \\
\text { primaquine secondary to } \\
\text { vomiting. } 1 \text { of } 19 \text { taking } \\
\text { doxycycline discontinued }\end{array}$ \\
\hline $\begin{array}{l}\text { Papua/open clinical } \\
\text { trial }^{100}\end{array}$ & $\begin{array}{l}N=45 \\
0.5 \mathrm{mg} / \mathrm{kg} / \text { every other day } \\
16-19 \text { weeks }\end{array}$ & $\begin{array}{l}\text { Headache, fever, } \\
\text { diarrhea, abdominal } \\
\text { pain, vomiting }\end{array}$ & Chloroquine & $\begin{array}{l}\text { None higher than that } \\
\text { associated with chloroquine } \\
\text { use }\end{array}$ \\
\hline $\begin{array}{l}\text { Thailand/open } \\
\text { randomized clinical } \\
\text { trial }^{47}\end{array}$ & $\begin{array}{l}N=81(15 \mathrm{mg} / \text { day }) \\
N=86(22.5 \mathrm{mg} / \text { day }) \\
14 \mathrm{~d}\end{array}$ & Not reported & Not reported & None noted \\
\hline $\begin{array}{l}\text { Colombia/randomized, } \\
\text { double-blind } \\
\text { placebo-controlled }^{14}\end{array}$ & $\begin{array}{l}N=100 \\
30 \mathrm{mg} / \mathrm{d}(+300 \mathrm{mg} \\
\text { chloroquine } / \mathrm{wk}) \\
17 \mathrm{wk}\end{array}$ & Gastrointestinal & Placebo & \\
\hline
\end{tabular}

ADRs, adverse drug reactions.

ated 11- and 20-week regimens of primaquine. ${ }^{11,14,16,100}$ Two studies examined toxicity of $30 \mathrm{mg}$ weekly to twice weekly for 9-12 months and found no evidence of long term toxicity. ${ }^{2,38}$ No data are available on use of primaquine for $>1$ year.

\section{THERAPEUTIC INDEX/OVERDOSE}

Primaquine has a chemotherapeutic index ${ }^{1}$ of $10 .{ }^{34}$ High doses, $60-240 \mathrm{mg} / \mathrm{d}$, lead to toxic reactions including abdominal cramps, nausea, and headache, and are also associated with cyanosis from methemoglobinemia. ${ }^{145}$

\section{DRUG INTERACTIONS}

Some antipyretics, analgesics, and sulfonamides may precipitate hemolysis in G6PD-deficient persons and compound hemolysis induced by primaquine. ${ }^{97,109,117}$ Methemoglobine-

\footnotetext{
${ }^{1}$ Chemotherapeutic index is the ratio of the largest tolerated dose divided by the smallest effective dose (in this case the dose capable of preventing nearly all relapses).
}

mia can be induced in HIV-infected individuals being treated for or prophylaxed against Pneumocystis jiroveci pneumonia with primaquine $30 \mathrm{mg} / \mathrm{d}$, especially in those currently or recently taking dapsone. ${ }^{127,146-149}$

Primaquine can be administered with oral contraceptives with no apparent interaction or interference with hepatic metabolism of the contraceptives. ${ }^{150}$ Clinical trials have shown that primaquine does not inhibit humoral or cellular immune responses after tetanus or tetanus/diphtheria vaccination. $^{136,137}$

Quinacrine seems to potentiate the toxicity of anti-malarial agents that are structurally related to primaquine, and the concomitant use of quinacrine and primaquine is not recommended. ${ }^{144,151}$

\section{SPECIAL POPULATIONS}

The pharmacokinetics of primaquine have not been studied in children, pregnant women or patients with renal or hepatic dysfunction. $^{152}$

Children. Although few studies document the safety and tolerability of primaquine in children, the drug has been used 
TABLE 4

Cost of anti-malarial drugs

\begin{tabular}{lc}
\hline \multicolumn{1}{c}{ Regimen } & $\begin{array}{c}\text { Cost for 14-day stay including } \\
\text { recommended }\end{array}$ \\
\hline Primaquine & $\$ 47.61$ \\
Chloroquine & $\$ 39.76$ \\
Doxycycline-generic & $\$ 11.00$ \\
Vibra-Tabs (Pfizer) & $\$ 142.28$ \\
Mefloquine & $\$ 84.64$ \\
Atovaquone/proguanil & $\$ 113.39$ \\
\hline
\end{tabular}

* Data taken from reference 170 with permission.

in children for $>50$ years. Weiss and others ${ }^{11}$ reported good tolerance with primaquine $(0.5 \mathrm{mg} / \mathrm{kg} / \mathrm{d})$ for primary prophylaxis in Kenyan children 9-14 years of age. In another study of primary prophylaxis, ${ }^{100}$ Baird and others included children as young as 7 years of age.

The lower age or weight limit of primaquine use has not been determined. Some public health authorities recommend that primaquine not be given to children $<4$ years of age because of the risk of hemolysis, ${ }^{153}$ and others recommend it not be used in children $<1$ year old. ${ }^{154,155}$ Some investigators avoid administering it to young children for radical cure of $P$. vivax. ${ }^{156}$ In some malaria control programs, it is not used for children $<1$ year of age $\mathrm{e}^{79,157}$ or for those $<3^{158}$ or 6 months of age in other programs. ${ }^{159,160}$ In Vanuatu, it is not given to children who weigh $<9 \mathrm{~kg}$. ${ }^{161}$ The American Academy of Pediatrics does not list a lower age limit for primaquine use, ${ }^{162}$ nor do some other authors ${ }^{163}$ and public health authorities. $^{5,6,164}$ Those who recommend against using primaquine in children do not cite data supporting their view. In vitro work does suggest, however, that neonatal erythrocytes may undergo endocytosis in response to primaquine (as well as to other drugs). ${ }^{165,166}$

In summary, limited data support the safety and efficacy of primaquine for primary prophylaxis in children 7 years of age and older. There is no evidence to suggest that children of any age who are not deficient in G6PD do not tolerate the drug, although data are lacking. Because the use of primaquine requires performance of a blood test to check G6PD level, and because of the requirement for daily administration of the drug, its use in small children may be problematic. There are other efficacious and better-studied drugs that can be administered to children to prevent malaria, including drugs that require once weekly administration and that do not require phlebotomy. Primaquine could, therefore, be considered as an alternative for children for whom other malaria chemoprophylactic regimens would either be ineffective or contraindicated.

Pregnant women. Primaquine may cause hemolysis and hydrops fetalis in fetuses, and because the G6PD status of the fetus is rarely known with certainty, administration of primaquine is contraindicated during pregnancy irrespective of the mother's G6PD status. ${ }^{167,168}$ Pregnant women who need primaquine for radical cure of $P$. vivax or $P$. ovale malaria should be treated after they have delivered and may be maintained on weekly chloroquine until delivery.

No data are available on primaquine use in breastfeeding women ${ }^{169}$ or excretion of primaquine in breast milk. As a precaution, breast-feeding infants should be tested for G6PD deficiency before primaquine is given to the mother. ${ }^{5}$
COST

For a 14-day trip to a malarious area, including doses taken before, during, and after malaria exposure, the estimated drug costs for prophylaxis are shown in Table $4 .{ }^{170}$ These costs do not include testing for G6PD deficiency for primaquine, nor do they include using primaquine for PART when chloroquine, doxycycline, mefloquine, or atovaquone/ proguanil are given. The estimated cost for G6PD testing is $\$ 25.00 .^{170}$

Received July 27, 2005. Accepted for publication April 13, 2006.

Acknowledgments: The findings and conclusions expressed are the personal views of the authors do not reflect the official views of the Department of Defense, Department of the Army, the Department of the Navy, or the Centers for Disease Control and Prevention. Presented at the Centers for Disease Control and Prevention Expert Meeting on Malaria Prevention, 29-30 January, 2003, Atlanta, Georgia.

Authors' addresses: David R. Hill, MD, DTM\&H, FRCP National Travel Health Network and Centre and London School of Hygiene \& Tropical Medicine Mortimer Market Centre, Capper Street, London WC1E 6AU, UK, E-mail: david.hill@uclh.org. J. Kevin Baird, PhD, Director, ALERTAsia Foundation The Eijkman Institute Jalan Diponegoro No.69, Jakarta 10430, Indonesia, E-mail: alerta@alertasia. org. Capt. Monica E. Parise, MD, Chief, U.S. Public Health Service, Division of Parasitic Diseases, National Center for Infectious Diseases, Centers for Disease Control and Prevention, 4770 Buford Highway, MS F22, Atlanta, GA 30341, E-mail: mparise@cdc.gov. Linda S Lewis, DVM, MPVM, Epidemiologist, Butte County Department of Public Health, 202 Mira Loma Drive, Oroville, CA 95965, E-mail: llewis@buttecounty.net. Edward T. Ryan, MD, DTM\&H, Director, Tropical \& Geographic Medicine Center, Division of Infectious Diseases, Massachusetts General Hospital, Jackson 504, 55 Fruit Street, Boston, MA 02114, E-mail: etryan@partners.org. Col. Alan J. Magill, MD, FACP, Director, Division of Experimental Therapeutics, Walter Reed Army Institute of Research, Silver Spring, MD 20910, E-mail: alan.magill@na.amedd.army.mil.

Disclaimer: None of the authors has a conflict of interest to declare.

\section{REFERENCES}

1. Kish MA, 2001. Guide to development of practice guidelines. Clin Infect Dis 32: 851-854.

2. Arnold J, Alving AS, Hockwald RS, Clayman CB, Dern RJ, Beutler E, Jeffery GM, 1954. The effect of continuous and intermittent primaquine therapy on the relapse rate of chesson strain vivax malaria. J Lab Clin Med 44: 429-438.

3. Baird JK, Wiady I, Sutanihardja A, Suradi, Purnomo, Basri H, Sekartuti, Ayomi E, Fryauff DJ, Hoffman SL, 2002. Short report: Therapeutic efficacy of chloroquine combined with primaquine against Plasmodium falciparum in northeastern Papua, Indonesia. Am J Trop Med Hyg 66: 659-660.

4. Pukrittayakamee S, Vanijanonta S, Chantra A, Clemens R, White NJ, 1994. Blood stage antimalarial efficacy of primaquine in Plasmodium vivax malaria. J Infect Dis 169: 932935.

5. Centers for Disease Control and Prevention, Kozarsky PE, Arguin PM, Navin AW, 2005. Health Information for International Travel 2005-2006. Philadelphia: Elsevier.

6. Health Canada, 2004. Canadian recommendations for the prevention and treatment of malaria among international travelers. Can Commun Dis Rep 30(S1): 1-62.

7. Baird JK, Fryauff DJ, Hoffman SL, 2003. Primaquine for prevention of malaria in travelers. Clin Infect Dis 37: 1659-1667.

8. Arnold J, Alving AS, Hockwald RS, Clayman CB, Dern RJ, Beutler E, Flanagan CL, Jeffery GM, 1955. The antimalarial action of primaquine against the blood and tissue stages of falciparum malaria (Panama, P-F-6 strain). J Lab Clin Med 46: 391-397.

9. Alving AS, Rucker K, Flanagan CL, 1959. Observations on pri- 
maquine in the prophylaxis and cure of vivax malaria. Proc VI Int Congr Trop Med Malar, 203-9. Lisbon, September 1959.

10. Powell RD, Brewer GJ, 1967. Effects of pyrimethamine, chlorguanide, and primaquine against exoerythrocytic forms of a strain of chloroquine-resistant Plasmodium falciparum from Thailand. Am J Trop Med Hyg 16: 693-698.

11. Weiss WR, Oloo AJ, Johnson A, Koech D, Hoffman SL, 1995. Daily primaquine is effective for prophylaxis against falciparum malaria in Kenya: comparison with mefloquine, doxycycline, and chloroquine plus proguanil. J Infect Dis 171: 15691575.

12. Baird JK, Basri H, Subianto B, Fryauff DJ, McElroy PD, Leksana B, Richie TL, Masbar S, Wignall FS, Hoffman SL, 1995. Treatment of chloroquine-resistant Plasmodium vivax with chloroquine and primaquine or halofantrine. J Infect Dis 171: 1678-1682.

13. Fryauff DJ, Baird JK, Basri H, Sumawinata I, Purnomo, Richie TL, Ohrt CK, Mouzin E, Church CJ, Richards AL, Subianto B, Sandjaja B, Wignall FS, Hoffman SL. 1995. Randomised placebo-controlled trial of primaquine for prophylaxis of falciparum and vivax malaria. Lancet 346: 1190-1193.

14. Soto J, Toledo J, Rodriguez M, Sanchez J, Herrera R, Padilla J, Berman J, 1998. Primaquine prophylaxis against malaria in nonimmune Colombian soldiers: efficacy and toxicity. A randomized, double-blind, placebo-controlled trial. Ann Intern Med 129: 241-244.

15. Soto J, Toledo J, Rodriquez M, Sanchez J, Herrera R, Padilla J, Berman J, 1999. Double-blind, randomized, placebo-controlled assessment of chloroquine/primaquine prophylaxis for malaria in nonimmune Colombian soldiers. Clin Infect Dis 29: 199-201.

16. Baird JK, Lacy MD, Basri H, Barcus MJ, Maguire JD, Bangs MJ, Gramzinski R, Sismadi P, Krisin, Ling J, Wiady I, Kusumaningsih M, Jones TR, Fryauff DJ, Hoffman SL, and the United States Naval Medical Research Unit 2 Clinical Trials Team, 2001. Randomized, parallel placebo-controlled trial of primaquine for malaria prophylaxis in Papua, Indonesia. Clin Infect Dis 33: 1990-1997.

17. Barry M, 1999. Primaquine prophylaxis against malaria. Ann Intern Med 130: 536-537.

18. Collins WE, Jeffery GM, 1996. Primaquine resistance in Plasmodium vivax. Am J Trop Med Hyg 55: 243-249.

19. Schwartz E, Regev-Yochay G, 1999. Primaquine as prophylaxis for malaria for nonimmune travelers: A comparison with mefloquine and doxycycline. Clin Infect Dis 29: 1502-1506.

20. Heppner DG Jr, Gasser RA Jr, Kester KE, 1999. Primaquine prophylaxis against malaria. Ann Intern Med 130: 536.

21. Schwartz E, Parise M, Kozarsky P, Cetron M, 2003. Delayed onset of malaria-implications for chemoprophylaxis in travelers. N Engl J Med 349: 1510-1516.

22. Elliott JH, O'Brien D, Leder K, Kitchener S, Schwartz E, Weld L, Brown GV, Kain KC, Torresi J, 2004. Imported Plasmodium vivax malaria: demographic and clinical features in nonimmune travelers. J Travel Med 11: 213-217.

23. Holtz TH, Kachur SP, MacArthur JR, Roberts JM, Barber AM, Steketee RW, Parise ME, 2001. Malaria surveillance-United States, 1998. Morbid Mortal Wkly Rep 50(No. SS-5): 1-18.

24. Causer LM, Newman RD, Barber AM, Roberts JM, Stennies G, Bloland PB, Parise ME, Steketee RW, 2002. Malaria surveillance-United States, 2000. Morbid Mortal Wkly Rep 51(No. SS-5): 9-23.

25. Newman RD, Barber AM, Roberts J, Holtz T, Steketee RW, Parise ME, 2002. Malaria surveillance-United States, 1999. Morbid Mortal Wkly Rep 51(No. SS-1): 15-28.

26. Filler S, Causer LM, Newman RD, Barber AM, Roberts JM, MacArthur J, Parise ME, Steketee RW, 2003. Malaria surveillance-United States, 2001. Morbid Mortal Wkly Rep 52(No. SS-5): $1-14$

27. Shah S, Filler S, Causer LM, Rowe AK, Bloland PB, Barber AM, Roberts JM, Desai MR, Parise ME, Steketee RW, 2004 Malaria surveillance-United States, 2002. Morbid Mortal Wkly Rep 53(No. SS-1): 21-34.

28. Eliades MJ, Shah S, Nguyen-Dinh P, Newman RD, Barber AM, Roberts JM, Mali S, Parise ME, Steketee R, 2005. Malaria
surveillance-United States, 2003. Morbid Mortal Wkly Rep 54(No. SS-2): 25-40

29. Skarbinski J, Eliades MJ, Causer LM, Barber AM, Mali S, Nguyen-Dinh P, Roberts JM, Parise ME, Slutsker L, Newman RD, 2006. Malaria surveillance-United States, 2004. Morbid Mortal Wkly Rep (No. SS-4): 23-37.

30. Newman RD, Parise ME, Barber AM, Steketee RW, 2004. Malaria-related deaths among U.S. travelers, 1963-2001. Ann Intern Med 141: 547-555.

31. Committee to Advise on Tropical Medicine and Travel (CATMAT), 2000. Canadian recommendations for the prevention and treatment of malaria among international travelers. Can Commun Dis Rep 26: 1-42.

32. Centers for Disease Control and Prevention, 2001. Health Information for International Travel, 2001-2002. Atlanta, GA: US Department of Health and Human Services.

33. Ehrman FC, Ellis JM, Young MD, 1945. Plasmodium vivax Chesson strain. Science 101: 377.

34. Edgcomb JH, Arnold J, Yount EH, Alving AS, Eichelberger L, 1950. Primaquine, SN 13272, a new curative agent in vivax malaria: A preliminary report. J Natl Malaria Soc 9: 285-292.

35. Ruhe DS, Cooper WC, Coatney GR, Josephson ES, 1949. Studies in human malaria. XV. The therapeutic action of pamaquine (plasmochin) against St. Elizabeth strain vivax malaria. Am J Hyg 49: 367-373.

36. Garrison PL, 1952. Status of primaquine. 2. Cure of Korean vivax malaria with pramaquine and primaquine. JAMA 149: 1562-1563.

37. Alving AS, Arnold J, Hockwald RS, Clayman CB, Dern RJ, Beutler E, Flanagan CL, 1955. Potentiation of the curative action of primaquine in vivax malaria by quinine and chloroquine. J Lab Clin Med 46: 301-306.

38. Clayman CB, Arnold J, Hockwold RS, Yount EH, Edgecomb $\mathrm{JH}$, Alving AS, 1952. Toxicity of primaquine in caucasians. JAMA 149: 1563-1568.

39. Hockwald RS, Arnold J, Clayman CB, Alving AS, 1952. Toxicity of primaquine in Negroes. JAMA 149: 1568-1570.

40. Alving AS, Johnson CF, Tarlov AR, Brewer GJ, Kellermeyer RW, Carson PE, 1960. Mitigation of the hemolytic effect of primaquine and enhancement of its action against erythrocytic forms of the Chesson strain of Plasmodium vivax by intermittent regimens of drug administration. A preliminary report. Bull World Health Organ 22: 621.

41. Clyde DF, Miller RM, DuPont HL, Hornick RB, 1971. Antimalarial effects of tetracyclines in man. J Trop Med Hyg 74: 238-242.

42. Cooper C, Myatt AV, Hernandez T, Jeffery GM, Coatney GR, 1953. Studies on human malaria. XXXI. Comparison of primaquine, isopentaquine, $\mathrm{SN}-3883$ and pamaquine as curative agents against sporozoite-induced Chesson strain vivax malaria. Am J Trop Med Hyg 2: 949-957.

43. Bradley JP, 1994. Drug-resistant Plasmodium vivax malaria. $N$ Z Med J 107: 228-229.

44. Looareesuwan S, Buchachart K, Wilairatana P, Chalermrut K, Rattanapong Y, Amradee S, Siripiphat S, Chullawichit S, Thimasan K, Ittiverakul M, Triampon A, Walsh DS, 1997. Primaquine-tolerant vivax malaria in Thailand. Ann Trop Med Parasitol 91: 939-943.

45. Charoenlarp P, Harinasuta T, 1973. Relapses of vivax malaria after a conventional course of primaquine and chloroquine: Report of 2 cases. Southeast Asian J Trop Med Public Health 4: 135-137.

46. Krotoski WA, 1980. Frequency of relapse and primaquine resistance in Southeast Asian vivax malaria. $N$ Engl J Med 303: 587.

47. Bunnag D, Karbwang J, Thanavibul A, Chittamas S, Ratanapongse $\mathrm{Y}$, Chalermrut $\mathrm{K}$, Bangchang $\mathrm{KN}$, Harinasuta $\mathrm{T}$, 1994. High dose of primaquine in primaquine resistant vivax malaria. Trans R Soc Trop Med Hyg 88: 218-219.

48. Kitchener S, Nasveld P, Bennett S, Torresi J, 2005. Adequate primaquine for vivax malaria. J Travel Med 12: 133-135.

49. Nayar JK, Baker RH, Knight JW, Sullivan JS, Morris CL, Richardson BB, Galland GG, Collins WE, 1997. Studies on a primaquine-tolerant strain of Plasmodium vivax from Brazil in Aotus and Saimiri monkeys. J Parasitol 83: 739-745.

50. Garavelli PL, Corti E, 1992. Chloroquine resistance in Plasmo- 
dium vivax: The first case in Brazil. Trans $R$ Soc Trop Med Hyg 86: 128.

51. Duarte EC, Pang LW, Ribeiro LC, Fontes CJ, 2001. Association of subtherapeutic dosages of a standard drug regimen with failures in preventing relapses of vivax malaria. Am J Trop Med Hyg 65: 471-476.

52. Arias AE, Corredor A, 1989. Low response of Colombian strains of Plasmodium vivax to classical antimalarial therapy. Trop Med Parasitol 40: 21-23.

53. Phillips EJ, Keystone JS, Kain KC, 1996. Failure of combined chloroquine and high-dose primaquine therapy for Plasmodium vivax malaria acquired in Guyana, South America. Clin Infect Dis 23: 1171-1173.

54. Gascon J, Gomez Arce JE, Menendez C, Valls ME, Corachan M, 1994. Poor response to primaquine in two cases of Plasmodium vivax malaria from Guatemala. Trop Geogr Med 46: 3233.

55. Smoak BL, DeFraites RF, Magill AJ, Kain KC, Wellde BT, 1997. Plasmodium vivax infections in U.S. Army troops: Failure of primaquine to prevent relapses in studies from Somalia. Am J Trop Med Hyg 56: 231-234.

56. Schwartz E, Regev-Yochay G, Kurnik D, 2000. Short report: A consideration of primaquine dose adjustment for radical cure of Plasmodium vivax malaria. Am J Trop Med Hyg 62: 393395.

57. Na DJ, Han JD, Cha DY, Song IK, Choi HW, Chung EA, Park CW, Choi JS, 1999. Imported tertian malaria resistant to primaquine. Korean J Intern Med 14: 86-89.

58. Spudick JM, Garcia LS, Graham DM, Haake DA, 2005. Diagnostic and therapeutic pitfalls associated with primaquinetolerant Plasmodium vivax. J Clin Microbiol 43: 978-981.

59. Kotwal RS, Wenzel RB, Sterling RA, Porter WD, Jordan NN, Petruccelli BP, 2005. An outbreak of malaria in US Army Rangers returning from Afghanistan. JAMA 293: 212-216.

60. Doherty JF, Day JH, Warhurst DC, Chiodini PL, 1997. Treatment of Plasmodium vivax malaria-time for a change? Trans $R$ Soc Trop Med Hyg 91: 76.

61. Miller LH, Wyler DJ, Glew RH, Collins WE, Contacos PG, 1974. Sensitivity of four Central American strains of Plasmodium vivax to primaquine. Am J Trop Med Hyg 23: 309-310.

62. Jelinek T, Nothdurft HD, von Sonnenburg F, Loscher T, 1995. Long-term efficacy of primaquine in the treatment of vivax malaria in nonimmune travelers. Am J Trop Med Hyg 52: 322324.

63. Rombo L, Edwards G, Ward SA, Eriksson G, Lindquist L, Lindberg A, Runehagen A, Bjorkman A, Hylander NO, 1987. Seven patients with relapses of Plasmodium vivax or $P$. ovale despite primaquine treatment. Trop Med Parasitol 38: 49-50.

64. Luxemburger C, van Vugt M, Jonathan S, McGready R, Looareesuwan S, White NJ, Nosten F, 1999. Treatment of vivax malaria on the western border of Thailand. Trans $R$ Soc Trop Med Hyg 93: 433-438.

65. Saint-Yves IF, 1977. Comparison of treatment schedules for Plasmodium vivax infections in the Solomon Islands. Papua New Guinea Med J 20: 62-65.

66. Luzzi GA, Warrell DA, Barnes AJ, Dunbar EM, 1992. Treatment of primaquine-resistant Plasmodium vivax malaria. Lancet 340: 310 .

67. Clyde DF, McCarthy VC, 1977. Radical cure of Chesson strain vivax malaria in man by 7 , not 14 , days of treatment with primaquine. Am J Trop Med Hyg 26: 562-563.

68. Baird JK, Hoffman SL, 2004. Primaquine therapy for malaria. Clin Infect Dis 39: 1336-1345.

69. Myat Phone K, Myint O, Aung N, Aye Lwin H, 1994. The use of primaquine in malaria infected patients with red cell glucose-6-phosphate dehydrogenase (G6PD) deficiency in Myanmar. Southeast Asian J Trop Med Public Health 25: 710-713.

70. Coatney GR, Getz ME, 1962. Primaquine and quinocide as curative agents against sporozoite-induced Chesson strain vivax malaria. Bull World Health Organ 27: 290-293.

71. Baird JK, Rieckmann KH, 2003. Can primaquine therapy for vivax malaria be improved? Trends Parasitol 19: 115-120.

72. Gogtay N, Garg M, Kadam V, Kamtekar K, Kshirsagar NA, 1998. A 5 days primaquine regimen as anti-relapse therapy for Plasmodium vivax. Trans $R$ Soc Trop Med Hyg 92: 341.
73. Gogtay NJ, Desai S, Kamtekar KD, Kadam VS, Dalvi SS, Kshirsagar NA, 1999. Efficacies of 5- and 14-day primaquine regimens in the prevention of relapses in Plasmodium vivax infections. Ann Trop Med Parasitol 93: 809-812.

74. Cedillos RA, Warren M, Jeffery GM, 1978. Field evaluation of primaquine in the control of Plasmodium vivax. Am J Trop Med Hyg 27: 466-472.

75. Contacos PG, Coatney GR, Collins WE, Briesch PE, Jeter MH, 1973. Five day primaquine therapy - an evaluation of radical curative activity against vivax malaria infection. Am J Trop Med Hyg 22: 693-695.

76. Baird JK, 1998. Primaquine as anti-relapse therapy for Plasmodium vivax. Trans $R$ Soc Trop Med Hyg 92: 687.

77. Villalobos-Salcedo JM, Tada MS, Kimura E, Menezes MJ, Pereira da Silva LH, 2000. In-vivo sensitivity of Plasmodium vivax isolates from Rondnia (western Amazon region, Brazil) to regimens including chloroquine and primaquine. Ann Trop Med Parasitol 94: 749-758.

78. Rowland M, Durrani N, 1999. Randomized controlled trials of 5- and 14-days primaquine therapy against relapses of vivax malaria in an Afghan refugee settlement in Pakistan. Trans $R$ Soc Trop Med Hyg 93: 641-643.

79. Yadav RS, Ghosh SK, 2002. Radical curative efficacy of five-day regimen of primaquine for treatment of Plasmodium vivax malaria in India. $J$ Parasitol 88: 1042-1044.

80. Mihaly GW, Ward SA, Edwards G, Nicholl DD, Orme ML, Breckenridge AM, 1985. Pharmacokinetics of primaquine in man. I. Studies of the absolute bioavailability and effects of dose size. Br J Clin Pharmacol 19: 745-750.

81. Price AH, Fletcher KA, 1986. Ethnic differences in the reactions to drugs and xenobiotics. The metabolism and toxicity of primaquine. Prog Clin Biol Res 214: 261-278.

82. Ward SA, Mihaly GW, Edwards G, Looareesuwan S, Phillips RE, Chanthavanich P, Warrell DA, Orme ML, Breckenridge AM, 1985. Pharmacokinetics of primaquine in man. II. Comparison of acute vs chronic dosage in Thai subjects. Br J Clin Pharmacol 19: 751-755.

83. Bhatia SC, Saraph YS, Revankar SN, Doshi KJ, Bharucha ED, Desai ND, Vaidya AB, Subrahmanyam D, Gupta KC, Satoskar RS, 1986. Pharmacokinetics of primaquine in patients with P. vivax malaria. Eur J Clin Pharmacol 31: 205-210.

84. Mihaly GW, Ward SA, Edwards G, Orme ML, Breckenridge AM, 1984. Pharmacokinetics of primaquine in man: identification of the carboxylic acid derivative as a major plasma metabolite. Br J Clin Pharmacol 17: 441-446.

85. Kennedy E, Frischer H, 1990. Distribution of primaquine in human blood: drug-binding to alpha 1-glycoprotein. J Lab Clin Med 116: 871-878.

86. Wernsdorfer WH, Trigg PI, 1984. Primaquine: Pharmacokinetics, Metabolism, Toxicity and Activity. New York: John Wiley \& Sons.

87. Bangchang KN, Karbwang J, Back DJ, 1992. Primaquine metabolism by human liver microsomes: Effect of other antimalarial drugs. Biochem Pharmacol 44: 587-590.

88. Parkhurst GW, Nora MV, Thomas RW, Carson PE, 1984. Highperformance liquid chromatographic-ultraviolet determination of primaquine and its metabolites in human plasma and urine. J Pharm Sci 73: 1329-1331.

89. Greaves J, Evans DA, Gilles HM, Fletcher KA, Bunnag D, Harinasuta T, 1980. Plasma kinetics and urinary excretion of primaquine in man. Br J Clin Pharmacol 10: 399-404.

90. Back DJ, Purba HS, Park BK, Ward SA, Orme ML, 1983. Effect of chloroquine and primaquine on antipyrine metabolism. $\mathrm{Br} \mathrm{J}$ Clin Pharmacol 16: 497-502.

91. Pelkonen O, Maenpaa J, Taavitsainen P, Rautio A, Raunio H, 1998. Inhibition and induction of human cytochrome P450 (CYP) enzymes. Xenobiotica 28: 1203-1253.

92. Bapiro TE, Egnell AC, Hasler JA, Masimirembwa CM, 2001. Application of higher throughput screening (HTS) inhibition assays to evaluate the interaction of antiparasitic drugs with cytochrome P450s. Drug Metab Dispos 29: 30-35.

93. Li XQ, Bjorkman A, Andersson TB, Gustafsson LL, Masimirembwa CM, 2003. Identification of human cytochrome $\mathrm{P}(450)$ s that metabolise anti-parasitic drugs and predictions of 
in vivo drug hepatic clearance from in vitro data. Eur J Clin Pharmacol 59: 429-442.

94. Raaska K, Neuvonen PJ, 2000. Ciprofloxacin increases serum clozapine and N-desmethylclozapine: a study in patients with schizophrenia. Eur J Clin Pharmacol 56: 585-589.

95. Grasela TH Jr, Dreis MW, 1992. An evaluation of the quinolone-theophylline interaction using the Food and Drug Administration spontaneous reporting system. Arch Intern Med 152: 617-621.

96. Bangchang KN, Karbwang J, Back DJ, 1992. Mefloquine metabolism by human liver microsomes. Effect of other antimalarial drugs. Biochem Pharmacol 43: 1957-1961.

97. Clyde DF, 1981. Clinical problems associated with the use of primaquine as a tissue schizontocidal and gametocytocidal drug. Bull World Health Organ 59: 391-395.

98. Aronoff GR, Berns JS, Brier ME, Golper TA, Morrison G, Singer I, Swan SK, Bennett WM, 1999. Drug Prescribing in Renal Failure: Dosing Guidelines for Adults. Philadelphia: American College of Physicians.

99. Singhasivanon V, Sabcharoen A, Attanath P, Chongsuphajaisiddhi T, Diquet B, Turk P, 1991. Pharmacokinetics of primaquine in healthy volunteers. Southeast Asian J Trop Med Public Health 22: 527-533.

100. Baird JK, Fryauff DJ, Basri H, Bangs MJ, Subianto B, Wiady I, Purnomo, Leksana B, Masbar S, Richie TL, Jones TR, Tjitra E, Wignall FS, Hoffman SL, 1995. Primaquine for prophylaxis against malaria among nonimmune transmigrants in Irian Jaya, Indonesia. Am J Trop Med Hyg 52: 479-484.

101. Phillips-Howard PA, Blaze M, Hurn M, Bradley DJ, 1986. Malaria prophylaxis: Survey of the response of British travellers to prophylactic advice. BMJ 293: 932-934.

102. Lobel HO, Phillips-Howard PA, Brandling-Bennett AD, Steffen R, Campbell CC, Houng AY, Were JBO, Moser R, 1990. Malaria incidence and prevention among European and North American travellers to Kenya. Bull World Health Organ 68: 209-215.

103. Hill DR, 2000. Health problems in a large cohort of Americans traveling to developing countries. J Travel Med 7: 259-266.

104. Rieckmann KH, Yeo AE, Davis DR, Hutton DC, Wheatley PF, Simpson R, 1993. Recent military experience with malaria chemoprophylaxis. Med J Aust 158: 446-449.

105. Newton JA, Schnepf GA, Wallace MR, Lobel HO, Kennedy CA, Oldfield ECI, 1994. Malaria in US marines returning from Somalia. JAMA 272: 397-399.

106. Powell RD, 1978. Chemoprophylaxis and malaria in American servicemen returning from Vietnam. Am J Trop Med Hyg 27: $1-5$.

107. Leslie T, Rab MA, Ahmadzai H, Durrani N, Fayaz M, Kolaczinski J, Rowland M, 2004. Compliance with 14-day primaquine therapy for radical cure of vivax malaria-a randomized placebo-controlled trial comparing unsupervised with supervised treatment. Trans $R$ Soc Trop Med Hyg 98: 168-173.

108. World Health Organization Working Group, 1989. Glucose-6phosphate dehydrogenase deficiency. Bull World Health Organ 67: 601-611.

109. Beutler E, 1978. Hemolytic Anemia in Disorders of Red Cell Metabolism. New York: Plenum Press.

110. Brewer GJ, Zarafonetis CJ, 1967. The haemolytic effect of various regimens of primaquine with chloroquine in American $\mathrm{Ne}$ groes with G6PD deficiency and the lack of an effect of various antimalarial suppressive agents on erythrocyte metabolism. Bull World Health Organ 36: 303-308.

111. Charoenlarp P, Areekul S, Harinasuta T, Sirivorasarn P, 1972. The haemolytic effect of a single dose of $45 \mathrm{mg}$ of primaquine in G-6-PD deficient Thais. J Med Assoc Thai 55: 631-638.

112. Pannacciulli I, Salvidio E, Tizianello A, Parravidino G, 1969. Hemolytic effects of standard single dosages of primaquine and chloroquine on G-6-PD-deficient caucasians. J Lab Clin Med 74: 653-661.

113. Reeve PA, Toaliu H, Kaneko A, Hall JJ, Ganczakowski M, 1992. Acute intravascular haemolysis in Vanuatu following a single dose of primaquine in individuals with glucose-6phosphate dehydrogenase deficiency. J Trop Med Hyg 95: 349351.

114. Aung Than B, Hla-Pe U, Thein T, 1970. Primaquine induced haemolysis in G-6-PD deficient Burmese. Trans $R$ Soc Trop Med Hyg 64: 785-786.

115. Looareesuwan S, Wilairatana P, Krudsood S, Treeprasertsuk S, Singhasivanon P, Bussaratid V, Chokjindachai W, Viriyavejakul P, Chalermrut K, Walsh DS, White J, 1999. Chloroquine sensitivity of Plasmodium vivax in Thailand. Ann Trop Med Parasitol 93: 225-230.

116. Charoenlarp P, Areekul S, Pholpothi T, Harinasuta T, 1973. The course of primaquine-induced haemolysis in G-6-PD-deficient Thais. J Med Assoc Thai 56: 392-397.

117. Beutler E, 1991. Glucose-6-phosphate dehydrogenase deficiency. N Engl J Med 324: 169-174.

118. Khoo KK, 1981. The treatment of malaria in glucose-6phosphate dehydrogenase deficient patients in Sabah. Ann Trop Med Parasitol 75: 591-595.

119. Karwacki JJ, Shanks GD, Kummalue T, Watanasook C, 1989. Primaquine induced hemolysis in a Thai soldier. Southeast Asian J Trop Med Public Health 20: 555-556.

120. Salvidio E, Pannacciulli I, Tizianello A, Ajmar F, 1967. Nature of hemolytic crises and the fate of G6PD deficient, drugdamaged erythrocytes in Sardinians. N Engl J Med 276: 1339_ 1344.

121. Beutler E, 1994. G6PD deficiency. Blood 84: 3613-3636.

122. Coleman MD, Coleman NA, 1996. Drug-induced methaemoglobinaemia. Treatment issues. Drug Saf 14: 394-405.

123. Cohen RJ, Sachs JR, Wicker DJ, Conrad ME, 1968. Methemoglobinemia provoked by malarial chemoprophylaxis in Vietnam. N Engl J Med 279: 1127-1131.

124. Fletcher KA, Evans DA, Gilles HM, Greaves J, Bunnag D, Harinasuta T, 1981. Studies on the pharmacokinetics of primaquine. Bull World Health Organ 59: 407-412.

125. Sietsma A, Naughton MA, Harley JD, 1971. Methaemoglobin levels in soldiers receiving antimalarial drugs. Med J Aust 1: 473-475.

126. Medina I, Mills J, Leoung G, Hopewell PC, Lee B, Modin G, Benowitz N, Wofsy CB, 1990. Oral therapy for Pneumocystis carinii pneumonia in the acquired immunodeficiency syndrome. A controlled trial of trimethoprim-sulfamethoxazole versus trimethoprim-dapsone. N Engl J Med 323: 776-782.

127. Sin DD, Shafran SD, 1996. Dapsone- and primaquine-induced methemoglobinemia in HIV-infected individuals. J Acquir Immune Defic Syndr Hum Retrovirol 12: 477-481.

128. Paul MA, McCarthy AE, Gibson N, Kenny G, Cook T, Gray G, 2003. The impact of Malarone and primaquine on psychomotor performance. Aviat Space Environ Med 74: 738-745.

129. Schlossberg D, 1980. Reaction to primaquine. Ann Intern Med 92: 435.

130. Thong YH, Ferrante A, Rowan-Kelly B, 1978. Primaquine inhibits mitogen-induced human lymphocyte proliferative responses. Trans $R$ Soc Trop Med Hyg 72: 537-539.

131. Ponnampalam JT, 1979. Immunosuppression caused by primaquine. Trans $R$ Soc Trop Med Hyg 73: 473-474.

132. Prasad RN, Garg SK, Mahajan RC, Ganguly NK, 1990. Primaquine: Its effect on cellular immune response of normal rhesus monkeys. J Commun Dis 22: 254-259.

133. Thong YH, Ferrante A, Secker LK, 1981. Normal immunological responses in mice treated with chloroquine, quinine and primaquine. Trans $R$ Soc Trop Med Hyg 75: 108-109.

134. Prasad RN, Virk KJ, Ganguly NK, Mahajan RC, 1991. Humoral immune response of normal rhesus monkeys during primaquine administration. J Commun Dis 23: 240-244.

135. Ferrante A, Goh DH, 1984. The effect of anti-malarial drugs on human natural killer cells in vitro. Parasite Immunol 6: 571580 .

136. Fryauff DJ, Mouzin E, Church LW, Ratiwayanto S, Hadiputranto H, Sutamihardja MA, Widjaja H, Corradin G, Subianto B, Hoffman SL, 1999. Lymphocyte response to tetanus toxin T-cell epitopes: Effects of tetanus vaccination and concurrent malaria prophylaxis. Vaccine 17: 59-63.

137. Fryauff DJ, Cryz SJ, Widjaja H, Mouzin E, Church LW, Sutamihardja MA, Richards AL, Subianto B, Hoffman SL, 1998. Humoral immune response to tetanus-diphtheria vaccine given during extended use of chloroquine or primaquine malaria chemoprophylaxis. J Infect Dis 177: 1762-1765.

138. Fryauff DJ, Richards AL, Baird JK, Richie TL, Mouzin E, Tjitra 
E, Sutamihardja MA, Ratiwayanto S, Hadiputranto H, Larasati RP, Pudjoprawoto N, Subianto B, Hoffman SL, 1996. Lymphocyte proliferative response and subset profiles during extended periods of chloroquine or primaquine prophylaxis. Antimicrob Agents Chemother 40: 2737-2742.

139. Fryauff DJ, Church LW, Richards AL, Widjaja H, Mouzin E, Ratiwayanto S, Hadiputranto H, Sutamihardja MA, Richie TL, Subianto B, Tjitra E, Hoffman SL, 1997. Lymphocyte response to tetanus toxoid among Indonesian men immunized with tetanus-diphtheria during extended chloroquine or primaquine prophylaxis. $J$ Infect Dis 176: 1644-1648.

140. Fryauff DJ, Prodjodipuro P, Basri H, Jones TR, Mouzin E, Widjaja H, Subianto B, 1998. Intestinal parasite infections after extended use of chloroquine or primaquine for malaria prevention. J Parasitol 84: 626-629.

141. Brennecke FE, 1951. A preliminary report on the effect of certain 8-aminoquinolines in the treatment of rheumatoid arthritis. Lab Clin Med 38: 795-796.

142. Jones R Jr, Jackson LS, Di Lorenzo A, Marx RL, Levy BL, Kenny EC, Gilbert M, Johnston MN, Alving AS, 1953. Korean vivax malaria. III. Curative effect and toxicity of primaquine in doses from 10 to $30 \mathrm{mg}$. daily. Am J Trop Med Hyg 2: 977-982.

143. Sanofi-Synthelabo, 1999. Product Information: Primaquine Brand of Phosphate Tablets. New York: Sanofi-Synthelabo.

144. USP DI Editorial Group, 2003. Primaquine (systemic). USP DI Drug Information for the Healthcare Provider. 23rd Edition. Taunton, MA: Micromedex, Inc.

145. Jaeger A, Sauder P, Kopferschmitt J, Flesch F, 1987. Clinical features and management of poisoning due to antimalarial drugs. Med Toxicol Adverse Drug Exp 2: 242-273.

146. Kantor GS, 1992. Primaquine-induced methemoglobinemia during treatment of Pneumocystis carinii pneumonia. $N$ Engl $J$ Med 327: 1461.

147. Dawson AH, Whyte IM, 1989. Management of dapsone poisoning complicated by methaemoglobinaemia. Med Toxicol Adverse Drug Exp 4: 387-392.

148. Safrin S, Finkelstein DM, Feinberg J, Frame P, Simpson G, Wu A, Cheung T, Soeiro R, Hojczyk P, Black JR, 1996. Comparison of three regimens for treatment of mild to moderate Pneumocystis carinii pneumonia in patients with AIDS. A double-blind, randomized, trial of oral trimethoprim-sulfamethoxazole, dapsone-trimethoprim, and clindamycinprimaquine. ACTG 108 Study Group. Ann Intern Med 124: 792-802.

149. Ruf B, Rohde I, Pohle HD, 1991. Efficacy of clindamycin/ primaquine versus trimethoprim/sulfamethoxazole in primary treatment of Pneumocystis carinii pneumonia. Eur J Clin Microbiol Infect Dis 10: 207-210.

150. Back DJ, Breckenridge AM, Grimmer SF, Orme ML, Purba HS, 1984. Pharmacokinetics of oral contraceptive steroids following the administration of the antimalarial drugs primaquine and chloroquine. Contraception 30: 289-295.

151. 2002. Primaquine phosphate. McEvoy GK, ed. AHFS Drug In- formation. Bethesda, MD: American Society of Health-System Pharmacists, Inc.

152. White NJ, 1985. Clinical pharmacokinetics of antimalarial drugs. Clin Pharmacokinet 10: 187-215.

153. 2001. The Use of Antimalarial Drugs. Report of a WHO Informal Consultation. Geneva: World Health Organization.

154. Luzzi GA, Peto TEA, 1993. Adverse effects of anti-malarials. An update. Drug Saf 8: 295-311.

155. Chongsuphajaisiddhi T, 1988. Malaria in paediatric practice. Wernsdorfer W, McGregor I, eds. Malaria. Principles and Practice of Malariology. London: Churchill Livingstone, 889902.

156. Da Silva AR, Pedrozo Silva C M, Branco Mdos R, Branco Filho JR, 1989. [Results of the use of a therapeutic protocol for Plasmodium vivax for 5 days in 3 municipalities of the Sao Luis island, State of Maranhao, Brazill. Rev Soc Bras Med Trop 22: 131-136.

157. Garfield RM, Vermund SH, 1983. Changes in malaria incidence after mass drug administration in Nicaragua. Lancet 2: 500503.

158. Kaneko A, Taleo G, Kalkoa M, Yamar S, Kobayakawa T, Bjorkman A, 2000. Malaria eradication on islands. Lancet 356: 1560-1564.

159. Ministerio de Salud. Politica national de medicamentos para el control de la malaria en Peru. Lima, Peru, 1999. 37.

160. Ministerio de Salud y Prevision Social, 2006. Manual de normas de tratamiento de la malaria. La Paz, Bolivia.

161. Reeve PA, 1994. Malaria treatment in Vanuatu: new national treatment guidelines. Papua New Guinea Med J 37: 181-188.

162. American Academy of Pediatrics, 2000. 2000 Red Book: Report of the Committee on Infectious Diseases. Elk Grove Village, IL: American Academy of Pediatrics.

163. Cooke IF, 1985. Plasmodium vivax malaria in children. Med $J$ Aust 142: 490-491.

164. Kramer MH, Lobel HO, 2001. Antimalarial chemoprophylaxis in infants and children. Paediatr Drugs 3: 113-121.

165. Matovcik LM, Junga IG, Schrier SL, 1985. Drug-induced endocytosis of neonatal erythrocytes. Blood 65: 1056-1063.

166. Thatte HS, Schrier SL, 1988. Comparison of transferrin receptor-mediated endocytosis and drug-induced endocytosis in human neonatal and adult RBCs. Blood 72: 1693-1700.

167. Phillips-Howard PA, Wood D, 1996. The safety of antimalarial drugs in pregnancy. Drug Saf 14: 131-145.

168. Davis TM, 1998. Adverse effects of antimalarial prophylactic drugs: an important consideration in the risk-benefit equation. Ann Pharmacother 32: 1104-1106.

169. Briggs GG, Freeman RK, Yaffe SJ, 2002. Primaquine. Mitchell CW, ed. Drugs in Pregnancy and Lactation. Baltimore: Williams \& Wilkins, 1154.

170. Bryan JP, 2006. Cost considerations for malaria chemoprophylaxis including use of primaquine for primary or terminal chemoprophylaxis. Am J Trop Med Hyg 75: 416-420. 